\title{
PHASE EQUILIBRIA IN THE Bi-In-Sn-Zn SYSTEM. THERMAL ANALYSIS VS. CALCULATIONS
}

\begin{abstract}
With the use of the differential thermal analysis (DTA), studies of the phase transitions were conducted for 90 of alloys from the quaternary Bi-In-Sn-Zn system and for the constant ratio of Bi:In and Bi:Sn. The studies were conducted for the alloys prepared from the purity metals ( $\mathrm{Bi}, \mathrm{In}, \mathrm{Sn}, \mathrm{Zn}=99.999$ mas. \%) by way of melting in a graphite crucible in a glove-box filled with $\mathrm{Ar}$, in which the impurities level was less than $0.1 \mathrm{ppm}$. After melting and thorough mixing, the liquid alloys were poured out into a graphite test mold. The phase transition temperature data obtained from the DTA investigations were next confronted with those determined from the calculations based on the binary and ternary optimized thermodynamic parameters available in the literature. It was found that the experimental and the calculated phase transition temperatures were in good agreement.

Keywords: Thermodynamics, Differential Thermal Analysis, Quaternary Alloys
\end{abstract}

\section{Introduction}

The quaternary Bi-In-Sn-Zn system is important for the lead-free solder technology because its Sn-rich alloys are potential substitutes of traditional lead solders based on the near eutectic $\mathrm{Pb}-\mathrm{Sn}$ alloys which have been used for many years in microelectronics. The first experimental data on the wettability of $\mathrm{Cu}$-substrates by Bi-In-Sn-Zn solders of a high Sn concentration were very promising [1] because of their low melting temperature being close to that for the $\mathrm{Pb}-\mathrm{Sn}$ eutectic $456 \mathrm{~K}\left(183^{\circ} \mathrm{C}\right)$, and their better mechanical properties, in particular the creep resistance and the tensile strength.

The improvement of the different properties of these leadfree solders needs a systematic updating of the thermo-physical properties as well as of the thermodynamic data base for the critical evaluation of all the experimental data available in the literature by means of the CALPHAD (Calculation of Alloys Phase Diagrams) method.

This procedure is based on sequential modeling of the phase equilibria and thermodynamic properties of alloy systems, starting from binary systems and extending to higher-order systems, to obtain accurate predictions of the phase equilibria in multicomponent systems. The crucial condition for the success of such a method is a well-updated CALPHAD database for the calculation of the thermodynamic properties of the relevant systems. The accuracy of such a database relies on the accuracy of the interaction energies assessed for the binary and the ternary systems. Ideally, these energies can be extracted from the available experimental data by applying different models.
Only limited information on the quaternary Bi-In-Sn-Zn system is available. Some Sn-rich alloys have been analyzed by differential scanning calorimetry [2] and their microstructure was examined with the use of SEM (Scanning Electron Microscopy) and XRD (X-Ray Diffraction). This is, basically, the only available data, as no extensive investigations of this type of quaternary alloys have been conducted, so far.

The Bi-In-Sn-Zn system was widely assessed by Moelans et al. [3], who used all the available thermodynamic data and assessed the thermodynamic parameters of the constituent binary systems. Using the CALPHAD method, they optimized the thermodynamic descriptions for the ternary Bi-In-Sn, Bi-In-Zn, $\mathrm{Bi}-\mathrm{Sn}-\mathrm{Zn}$ and $\mathrm{In}-\mathrm{Sn}-\mathrm{Zn}$ systems, and combined them to obtain a description of the quaternary Bi-In-Sn-Zn system. Because Moelans et al. [3] provide no information on the thermodynamic properties and topology of the $\mathrm{Bi}-\mathrm{In}-\mathrm{Zn}$ system, an approximate description was elaborated to reproduce the liquid miscibility gap with a plausible shape. In the present work, the new assessment of the Bi-In-Zn system [4] was adopted, which was performed with the use of the new experimental data: the DTA analysis of 15 samples by the DTA technique in the temperature range of $300-900 \mathrm{~K}\left(27-627^{\circ} \mathrm{C}\right)$ [4], the enthalpy of mixing of liquid alloys [5] determined at $773 \mathrm{~K}\left(500^{\circ} \mathrm{C}\right)$ and $873 \mathrm{~K}\left(600^{\circ} \mathrm{C}\right)$ by the drop calorimetric technique in a Calvet-type micro-calorimeter and the zinc activity [6] of the liquid Bi-In-Zn solutions obtained from the e.m.f. ( $\mathrm{LiCl}+\mathrm{KCl}+\mathrm{Zn}$ electrolyte) method.

In this work, DTA studies of the transition temperatures were conducted for 90 of $\mathrm{Bi}-\mathrm{In}-\mathrm{Sn}-\mathrm{Zn}$ alloys for selected ratios of the mole concentrations. These calculations were conducted

\footnotetext{
* INSTITUTE OF METALLURGY AND MATERIALS SCIENCE, POLISH ACADEMY OF SCIENCES, 30-059 KRAKÓW, 25 REYMONTA STR., POLAND

** AGH UNIVERSITY OF SCIENCE AND TECHNOLOGY, AL. MICKIEWICZA 30, 30-059 KRAKOW, POLAND

\# Corresponding author: w.gasior@imim.pl
} 
based on the interaction parameters for the binary and ternary systems available in the literature [4,7]. Therefore, the thermodynamic database of quaternary Bi-In-Sn-Zn system was combined from assessments of four constituent ternary systems. It is a common practice for multicomponent systems because of lack of thermodynamic data. The control experiments (for example DTA) allow to check the accuracy of such description. For this purpose the DTA experimental data and those obtained from the phase equilibria calculations were compared. Otherwise, the present work can be treated as such check of coherency of optimized ternary parameters.

\section{DTA study of Bi-In-Sn-Zn system}

\subsection{Alloys preparation}

The Bi-In-Sn-Zn alloys were prepared from metals: In 99.999 mass. \% (Indium Corporation, USA), Bi, Sn and Zn all 99.999 mass. \% (ITME, Warsaw, Poland). The weighed amounts of pure metals were melted in graphite crucibles in a glove box under purified $\mathrm{Ar}$ (impurities $<0.1 \mathrm{ppm}$ ). After heating up to $773 \mathrm{~K}\left(500^{\circ} \mathrm{C}\right)$ and mixing of the components, the resulting alloys were cast into a graphite sample mold. All together 90 alloys with $\mathrm{Zn}$ concentration changing from 0.05 to 0.9 mole fraction and the different ratios of the remaining components: Bi:In (0.25, 0.5 and 0.75) and Bi:Sn (0.067, 0.111, 0.143, 0.2, $0.333,0.428,0.5,0.6,1.286)$ were produced. The concentrations of all the alloys applied in our studies are presented in the next part, together with the results of the phase transition temperatures from the DTA studies.

\subsection{Apparatus}

The Bi-In-Sn-Zn system was studied by the DTA method with the use of a modified Q-1500 D (Paulik-Paulik-Erdey) (MOM, Hungary) apparatus working up to $1300 \mathrm{~K}\left(1027^{\circ} \mathrm{C}\right)$. Based on the many calibration measurements of the pure metals, the accuracy of the DTA results is less than $\pm 2 \mathrm{~K}$ for Q-1500 D. The alloy samples of about 1 gram were placed into alumina crucibles after the division of the cast material into 2 parts. Using Q-1500 D the DTA heating and cooling cycle rate was $5 \mathrm{deg} / \mathrm{min}$ in the temperature range from 300 up to max. $900 \mathrm{~K}$ (27-627 ${ }^{\circ} \mathrm{C}$ ) limit taking into account the temperature of the miscibility gap boundary. And so, most of the alloys were investigated at temperatures lower than $700 \mathrm{~K}\left(427^{\circ} \mathrm{C}\right)$. To avoid a concentration change of the alloys due to zinc evaporation, the DTA investigations were performed only in one heating and cooling cycle. In comparison to the partial pressure of $\mathrm{Zn}$, the partial pressures of $\mathrm{Bi}$ and $\mathrm{In}$ at temperatures lower than $900 \mathrm{~K}\left(627^{\circ} \mathrm{C}\right)$ are several orders of magnitude lower. Therefore, their contents in the samples should not change considerably during the experiments.

Additionally, to test the reliability of the presented thermal analysis results, DTA measurements were performed with the use of and DSC/DTA Pegasus 404 F1 (Netzsch, Germany) scanning calorimeter with a DTA probe, in a similar temperature range. According to the recommendations of Boettinger at al. [10] the univariant and invariant transitions were determined from onset temperatures and the liquidus from the last peak of DTA signal. The samples groups of numbers $(23,25,27),(51,53,57)$ and $(87,89)$ were analyzed in $40-770 \mathrm{~K}\left(-233-497^{\circ} \mathrm{C}\right)$ temperature range with the heating and cooling rates of $2 \mathrm{deg} / \mathrm{min}$ in two consecutive cycles. Also the samples no. 37, 38 and 68 were measured with the heating and cooling rates of $2 \mathrm{deg} / \mathrm{min}$ and $5 \mathrm{deg} / \mathrm{min}$. The apparatus was calibrated for the melting point of pure metals (min. 99.999 mas.\%): In, Sn, Zn, Pb, Sb and Ag. The samples were sealed in evacuated silica tubes and placed at a DTA sensor in a platinum crucible. An empty evacuated silica tube in a platinum crucible was used as a reference state. No traces of $\mathrm{Zn}$ evaporation was observed at inner surface of quartz tubes.

In the following publication the abbreviations Q-1500 D and Netzsch 404 DTA for the DTA devices were used.

\subsection{Results}

The DTA studies were performed by Q-1500 D in two series of heating and cooling with the heating rate equaling $5 \mathrm{deg} /$ min, and the obtained results are shown in Table 1a-i and in Figs 1a-i. The concentrations of the components in the Tables are in atomic percentage.

TABLE 1a

The DTA results of Bi-In-Sn-Zn alloys. Cross sections: $(\mathrm{Bi}: \mathrm{In}=0.25$ and $\mathrm{Bi}: \mathrm{Sn}=0.6)+\%$ at. $\mathrm{Zn}$

\begin{tabular}{|c|c|c|c|c|c|}
\hline \hline $\begin{array}{c}\text { Sample } \\
\text { no. }\end{array}$ & $\begin{array}{c}\mathbf{B i} \\
\text { \% at. }\end{array}$ & $\begin{array}{c}\text { In } \\
\text { \% at. }\end{array}$ & $\begin{array}{c}\text { Sn } \\
\text { \% at. }\end{array}$ & $\begin{array}{c}\text { Zn } \\
\text { \% at. }\end{array}$ & $\begin{array}{c}\text { Registered DTA } \\
\text { thermal arrests, }{ }^{\circ} \mathbf{C}\end{array}$ \\
\hline 1 & 14.25 & 57.00 & 23.75 & 5.00 & $61 ; 67$ \\
\hline 2 & 13.50 & 54.00 & 22.50 & 10.00 & $61 ; 69$ \\
\hline 3 & 12.00 & 48.00 & 20.00 & 20.00 & $61 ; 67 ; 290^{*}$ \\
\hline 4 & 10.50 & 42.00 & 17.50 & 30.00 & $61 ; 68 ; 324$ \\
\hline 5 & 9.00 & 36.00 & 15.00 & 40.00 & $63 ; 354$ \\
\hline 6 & 7.50 & 30.00 & 12.50 & 50.00 & $64 ; 366$ \\
\hline 7 & 6.00 & 24.00 & 10.00 & 60.00 & $51 ; 89 ; 357$ \\
\hline 8 & 4.50 & 18.00 & 7.50 & 70.00 & $60 ; 362$ \\
\hline 9 & 3.00 & 12.00 & 5.00 & 80.00 & $60 ; 365$ \\
\hline 10 & 1.50 & 6.00 & 2.50 & 90.00 & $60 ; 371$ \\
\hline
\end{tabular}

* Weak thermal signals.

For some alloys, the signals at the DTA diagram were observed only in one cycle (cooling or heating) and they were designated in Table 1a-i by a question mark. It should also be noted that, for the same samples, even for the cooling velocity equaling $2 \mathrm{deg} / \mathrm{min}$, an undercooling of about $10^{\circ} \mathrm{C}$ was observed. Very weak thermal signals were also registered, which were not observed in the other samples or the thermal cycles. These results were additionally marked in Table 1a-i by an asterisk. 
TABLE $1 b$

TABLE 1e

The DTA results of Bi-In-Sn-Zn alloys.

Cross sections: $(\mathrm{Bi}: \mathrm{In}=0.25$ and $\mathrm{Bi}: \mathrm{Sn}=0.2)+\%$ at. $\mathrm{Zn}$

\begin{tabular}{|c|c|c|c|c|c|}
\hline \hline $\begin{array}{c}\text { Sample } \\
\text { no. }\end{array}$ & $\begin{array}{c}\text { Bi } \\
\text { \% at. }\end{array}$ & $\begin{array}{c}\text { In } \\
\text { \% at. }\end{array}$ & $\begin{array}{c}\text { Sn } \\
\text { \% at. }\end{array}$ & $\begin{array}{c}\text { Zn } \\
\text { \% at. }\end{array}$ & $\begin{array}{c}\text { Registered DTA } \\
\text { thermal arrests, }{ }^{\circ} \mathbf{C}\end{array}$ \\
\hline 11 & 9.50 & 38.00 & 47.50 & 5.00 & $60 ; 115$ \\
\hline 12 & 9.00 & 36.00 & 45.00 & 10.00 & $60 ; 115 ; 197 *$ \\
\hline 13 & 8.00 & 32.00 & 40.00 & 20.00 & $60 ; 109 ; 120 ; 261$ \\
\hline 14 & 7.00 & 28.00 & 35.00 & 30.00 & $60 ; 115 ; 299$ \\
\hline 15 & 6.00 & 24.00 & 30.00 & 40.00 & $61 ; 72 ; 121 ; 331$ \\
\hline 16 & 5.00 & 20.00 & 25.00 & 50.00 & $61 ; 73 ; 123 ; 351$ \\
\hline 17 & 4.00 & 16.00 & 20.00 & 60.00 & $51 ; 115 ; 351$ \\
\hline 18 & 3.00 & 12.00 & 15.00 & 70.00 & $51 ; 118 ; 357$ \\
\hline 19 & 2.00 & 8.00 & 10.00 & 80.00 & $53 ; 112 ; 355$ \\
\hline 20 & 1.00 & 4.00 & 5.00 & 90.00 & 373 \\
\hline
\end{tabular}

* Weak thermal signals.

TABLE 1c

The DTA results of Bi-In-Sn-Zn alloys.

Cross sections: $(\mathrm{Bi}: \mathrm{In}=0.25$ and $\mathrm{Bi}: \mathrm{Sn}=0.067)+\%$ at. $\mathrm{Zn}$

\begin{tabular}{|c|c|c|c|c|c|}
\hline $\begin{array}{c}\text { Sample } \\
\text { no. }\end{array}$ & $\begin{array}{c}\mathbf{B i} \\
\text { \% at. }\end{array}$ & $\begin{array}{c}\text { In } \\
\text { \% at. }\end{array}$ & $\begin{array}{c}\text { Sn } \\
\text { \% at. }\end{array}$ & $\begin{array}{c}\text { Zn } \\
\text { \% at. }\end{array}$ & $\begin{array}{c}\text { Registered DTA } \\
\text { thermal arrests, }{ }^{\circ} \mathbf{C}\end{array}$ \\
\hline 21 & 4.75 & 19.00 & 71.25 & 5.00 & $131 ; 166$ \\
\hline 22 & 4.50 & 18.00 & 67.50 & 10.00 & $131 ; 174$ \\
\hline 23 & 4.00 & 16.00 & 60.00 & 20.00 & $125 ; 160 ; 240$ \\
\hline 24 & 3.50 & 14.00 & 52.50 & 30.00 & $126 ; 160 ; 279$ \\
\hline 25 & 3.00 & 12.00 & 45.00 & 40.00 & $146 ; 311$ \\
\hline 26 & 2.50 & 10.00 & 37.50 & 50.00 & $148 ; 338$ \\
\hline 27 & 2.00 & 8.00 & 30.00 & 60.00 & $155 ; 339$ \\
\hline 28 & 1.50 & 6.00 & 22.50 & 70.00 & $155 ; 347$ \\
\hline 29 & 1.00 & 4.00 & 15.00 & 80.00 & $156 ; 365$ \\
\hline 30 & 0.50 & 2.00 & 7.50 & 90.00 & $156 ; 373$ \\
\hline
\end{tabular}

TABLE 1d

The DTA results of Bi-In-Sn-Zn alloys.

Cross sections: $(\mathrm{Bi}: \mathrm{In}=0.5$ and $\mathrm{Bi}: \mathrm{Sn}=1)+\%$ at. $\mathrm{Zn}$

\begin{tabular}{|c|c|c|c|c|c|}
\hline \hline $\begin{array}{c}\text { Sample } \\
\text { no. }\end{array}$ & $\begin{array}{c}\text { Bi } \\
\text { \% at. }\end{array}$ & $\begin{array}{c}\text { In } \\
\text { \% at. }\end{array}$ & $\begin{array}{c}\text { Sn } \\
\text { \% at. }\end{array}$ & $\begin{array}{c}\text { Zn } \\
\text { \% at. }\end{array}$ & $\begin{array}{c}\text { Registered DTA } \\
\text { thermal arrests, }{ }^{\circ} \mathbf{C}\end{array}$ \\
\hline 31 & 23.75 & 47.50 & 23.75 & 5.00 & $60 ; 73$ \\
\hline 32 & 22.50 & 45.00 & 22.50 & 10.00 & $62 ; 75 ; 232 *$ \\
\hline 33 & 20.00 & 40.00 & 20.00 & 20.00 & $66 ; 77$ \\
\hline 34 & 17.50 & 35.00 & 17.50 & 30.00 & $67 ; 339 *$ \\
\hline 35 & 15.00 & 30.00 & 15.00 & 40.00 & $60 ; 368$ \\
\hline 36 & 12.50 & 25.00 & 12.50 & 50.00 & $66 ; 377$ \\
\hline 37 & 10.00 & 20.00 & 10.00 & 60.00 & $55 ; 367 ; 394$ \\
\hline 38 & 7.50 & 15.00 & 7.50 & 70.00 & $59 ; 367 ; 419$ \\
\hline 39 & 5.00 & 10.00 & 5.00 & 80.00 & $60 ; 374$ \\
\hline 40 & 2.50 & 5.00 & 2.50 & 90.00 & $59 ; 380$ \\
\hline
\end{tabular}

* Weak thermal signals.

The results obtained from additional DTA measurements (Netzsch 404 DTA) for selected samples are given in Table $2 a-b$ and were superimposed in Figs 1c-d, Figs 1f-g, and Fig. 1i, as the mean values of the transition temperatures determined based on two heating and cooling cycles. The difference between the results of the onset temperatures of two heating cycles was lower
The DTA results of Bi-In-Sn-Zn alloys.

Cross sections: $(\mathrm{Bi}: \mathrm{In}=0.5$ and $\mathrm{Bi}: \mathrm{Sn}=0.33)+\%$ at. $\mathrm{Zn}$

\begin{tabular}{|c|c|c|c|c|c|}
\hline \hline $\begin{array}{c}\text { Sample } \\
\text { no. }\end{array}$ & $\begin{array}{c}\text { Bi } \\
\text { \% at. }\end{array}$ & $\begin{array}{c}\text { In } \\
\text { \% at. }\end{array}$ & $\begin{array}{c}\text { Sn } \\
\text { \% at. }\end{array}$ & $\begin{array}{c}\text { Zn } \\
\text { \% at. }\end{array}$ & $\begin{array}{c}\text { Registered DTA } \\
\text { thermal arrests, }{ }^{\circ} \mathbf{C}\end{array}$ \\
\hline 41 & 15.83 & 31.67 & 47.50 & 5.00 & $60 ; 124$ \\
\hline 42 & 15.00 & 30.00 & 45.00 & 10.00 & $60 ; 124$ \\
\hline 43 & 13.33 & 26.67 & 40.00 & 20.00 & $60 ; 124$ \\
\hline 44 & 11.67 & 23.33 & 35.00 & 30.00 & $61 ; 125 ; 311$ \\
\hline 45 & 10.00 & 20.00 & 30.00 & 40.00 & $63 ; 124 ; 340$ \\
\hline 46 & 8.33 & 16.67 & 25.00 & 50.00 & $70 ; 124 ; 359$ \\
\hline 47 & 6.67 & 13.33 & 20.00 & 60.00 & $57 ; 118 ; 356$ \\
\hline 48 & 5.00 & 10.00 & 15.00 & 70.00 & $65 ; 117 ; 363$ \\
\hline 49 & 3.33 & 6.67 & 10.00 & 80.00 & $60 ; 124 ; 368$ \\
\hline 50 & 1.67 & 3.33 & 5.00 & 90.00 & 375 \\
\hline
\end{tabular}

TABLE $1 f$

The DTA results of Bi-In-Sn-Zn alloys.

Cross sections: $(\mathrm{Bi}: \mathrm{In}=0.5$ and $\mathrm{Bi}: \mathrm{Sn}=0.11)+\%$ at. $\mathrm{Zn}$

\begin{tabular}{|c|c|c|c|c|c|}
\hline $\begin{array}{c}\text { Sample } \\
\text { no. }\end{array}$ & $\begin{array}{c}\text { Bi } \\
\text { \% at. }\end{array}$ & $\begin{array}{c}\text { In } \\
\text { \% at. }\end{array}$ & $\begin{array}{c}\text { Sn } \\
\text { \% at. }\end{array}$ & $\begin{array}{c}\text { Zn } \\
\text { \% at. }\end{array}$ & $\begin{array}{c}\text { Registered DTA } \\
\text { thermal arrests, }{ }^{\circ} \mathbf{C}\end{array}$ \\
\hline 51 & 7.92 & 15.83 & 71.25 & 5.00 & $63 ; 153 ; 166$ \\
\hline 52 & 7.50 & 15.00 & 67.50 & 10.00 & $63 ; 161 ; 179$ \\
\hline 53 & 6.67 & 13.33 & 60.00 & 20.00 & $161 ; 244$ \\
\hline 54 & 5.83 & 11.67 & 52.50 & 30.00 & $161 ; 288$ \\
\hline 55 & 5.00 & 10.00 & 45.00 & 40.00 & 321 \\
\hline 56 & 4.17 & 8.33 & 37.50 & 50.00 & 327 \\
\hline 57 & 3.33 & 6.67 & 30.00 & 60.00 & 345 \\
\hline 58 & 2.50 & 5.00 & 22.50 & 70.00 & 354 \\
\hline 59 & 1.67 & 3.33 & 15.00 & 80.00 & 365 \\
\hline 60 & 0.83 & 1.67 & 7.50 & 90.00 & 374 \\
\hline
\end{tabular}

TABLE $1 \mathrm{~g}$

The DTA results of Bi-In-Sn-Zn alloys.

Cross sections: $(\mathrm{Bi}: \mathrm{In}=0.75$ and $\mathrm{Bi}: \mathrm{Sn}=1.286)+\%$ at. $\mathrm{Zn}$

\begin{tabular}{|c|c|c|c|c|c|}
\hline $\begin{array}{c}\text { Sample } \\
\text { no. }\end{array}$ & $\begin{array}{c}\text { Bi } \\
\text { \% at. }\end{array}$ & $\begin{array}{c}\text { In } \\
\text { \% at. }\end{array}$ & $\begin{array}{c}\text { Sn } \\
\text { \% at. }\end{array}$ & $\begin{array}{c}\text { Zn } \\
\text { \% at. }\end{array}$ & $\begin{array}{c}\text { Registered DTA } \\
\text { thermal arrests, }{ }^{\circ} \mathbf{C}\end{array}$ \\
\hline 61 & 30.54 & 40.71 & 23.75 & 5.00 & $60 ? ; 73 ; 186$ \\
\hline 62 & 28.93 & 38.57 & 22.50 & 10.00 & $60 ; 73 ; 243$ \\
\hline 63 & 25.71 & 34.29 & 20.00 & 20.00 & $619 ; 73 ; 312$ \\
\hline 64 & 22.50 & 30.00 & 17.50 & 30.00 & $61 ? ; 74 ; 355$ \\
\hline 65 & 19.29 & 25.71 & 15.00 & 40.00 & $65 ; 263 ; 340$ \\
\hline 66 & 16.07 & 21.43 & 12.50 & 50.00 & $65 ; 373$ \\
\hline 67 & 12.86 & 17.14 & 10.00 & 60.00 & $76 ; 376$ \\
\hline 68 & 9.64 & 12.86 & 7.50 & 70.00 & $75 ; 302 ; 375$ \\
\hline 69 & 6.43 & 8.57 & 5.00 & 80.00 & $60 ; 80 ; 371$ \\
\hline 70 & 3.21 & 4.29 & 2.50 & 90.00 & $60 ; 78 ; 381$ \\
\hline
\end{tabular}

? Thermal arrest detected for cooling.

than $\pm 2^{\circ} \mathrm{C}$ (Figs 2a-b). In the case of sample 68 ( $2 \mathrm{deg} / \mathrm{min}$ heating cycle - Table $2 \mathrm{~b}$ ) a significant difference between the beginning of the signal change (b) and the onset temperature of about $\sim 4.8^{\circ} \mathrm{C}$ can be observed (Fig. 3.). In the case of doubled cycles acquired with different cooling rates the difference between the peak endset temperatures was about $\pm 0.5^{\circ} \mathrm{C}$. 
TABLE $1 \mathrm{~h}$

The DTA results of Bi-In-Sn-Zn alloys. Cross sections: $(\mathrm{Bi}: \mathrm{In}=0.75$ and $\mathrm{Bi}: \mathrm{Sn}=0.43)+\%$ at. $\mathrm{Zn}$

\begin{tabular}{|c|c|c|c|c|c|}
\hline \hline $\begin{array}{c}\text { Sample } \\
\text { no. }\end{array}$ & $\begin{array}{c}\text { Bi } \\
\text { \% at. }\end{array}$ & $\begin{array}{c}\text { In } \\
\text { \% at. }\end{array}$ & $\begin{array}{c}\text { Sn } \\
\text { \% at. }\end{array}$ & $\begin{array}{c}\text { Zn } \\
\text { \% at. }\end{array}$ & $\begin{array}{c}\text { Registered DTA } \\
\text { thermal arrests, }{ }^{\circ} \mathbf{C}\end{array}$ \\
\hline 71 & 20.36 & 27.14 & 47.50 & 5.00 & $61 ; 80 ; 125 ; 376^{*}$ \\
\hline 72 & 19.29 & 25.71 & 45.00 & 10.00 & $78 ; 121 ; 196$ \\
\hline 73 & 17.14 & 22.86 & 40.00 & 20.00 & $125 ; 273$ \\
\hline 74 & 15.00 & 20.00 & 35.00 & 30.00 & $63 ; 125 ; 316$ \\
\hline 75 & 12.86 & 17.14 & 30.00 & 40.00 & $63 ; 125 ; 346$ \\
\hline 76 & 10.71 & 14.29 & 25.00 & 50.00 & $62 ; 125 ; 364$ \\
\hline 77 & 8.57 & 11.43 & 20.00 & 60.00 & $\begin{array}{c}75 ; 125 ; 266 ; 332 ; \\
360\end{array}$ \\
\hline 78 & 6.43 & 8.57 & 15.00 & 70.00 & $75 ; 125 ; 369$ \\
\hline 79 & 4.29 & 5.71 & 10.00 & 80.00 & $78 ; 125 ; 372$ \\
\hline 80 & 2.14 & 2.86 & 5.00 & 90.00 & $75 ; 125 ; 376$ \\
\hline
\end{tabular}

* Weak thermal signals.

TABLE 11

The DTA results of Bi-In-Sn-Zn alloys.

Cross sections: $(\mathrm{Bi}: \mathrm{In}=0.75$ and $\mathrm{Bi}: \mathrm{Sn}=0.143)+\%$ at. $\mathrm{Zn}$

\begin{tabular}{|c|c|c|c|c|c|}
\hline \hline $\begin{array}{c}\text { Sample } \\
\text { no. }\end{array}$ & $\begin{array}{c}\mathbf{B i} \\
\mathbf{\%} \text { at. }\end{array}$ & $\begin{array}{c}\mathbf{I n} \\
\mathbf{\%} \text { at. }\end{array}$ & $\begin{array}{c}\text { Sn } \\
\text { \% at. }\end{array}$ & $\begin{array}{c}\text { Zn } \\
\text { \% at. }\end{array}$ & $\begin{array}{c}\text { Registered DTA } \\
\text { thermal arrests, }\end{array}$ \\
\hline 81 & 10.18 & 13.57 & 71.25 & 5.00 & $61 ; 164$ \\
\hline 82 & 9.64 & 12.86 & 67.50 & 10.00 & $66 ; 160 ; 182$ \\
\hline 83 & 8.57 & 11.43 & 60.00 & 20.00 & $61 ; 161 ; 246$ \\
\hline 84 & 7.50 & 10.00 & 52.50 & 30.00 & $64 ; 160 ; 289$ \\
\hline 85 & 6.43 & 8.57 & 45.00 & 40.00 & $62 ; 161 ; 319$ \\
\hline 86 & 5.36 & 7.14 & 37.50 & 50.00 & $63 ; 161 ; 345$ \\
\hline 87 & 4.29 & 5.71 & 30.00 & 60.00 & $78 ; 344$ \\
\hline 88 & 3.21 & 4.29 & 22.50 & 70.00 & $78 ; 357$ \\
\hline 89 & 2.14 & 2.86 & 15.00 & 80.00 & $147 ? ; 363$ \\
\hline 90 & 1.07 & 1.43 & 7.50 & 90.00 & $145 ? ; 378$ \\
\hline
\end{tabular}

? Thermal arrest detected at cooling.

TABLE $2 \mathrm{a}$

The results of DTA experiments for quaternary Bi-In-Sn-Zn alloys of chosen compositions acquired

by DTA/DSC Pegasus 404 F1 (Netzsch, Germany)

\begin{tabular}{|c|c|c|c|c|c|c|}
\hline $\begin{array}{c}\text { Sample } \\
\text { no. } \\
\end{array}$ & $\begin{array}{c}\mathbf{B i} \\
\text { at. \% } \\
\end{array}$ & $\begin{array}{c}\text { In } \\
\text { at. \% }\end{array}$ & $\begin{array}{c}\text { Sn } \\
\text { at. \% }\end{array}$ & $\begin{array}{c}\mathrm{Zn} \\
\text { at. \% } \\
\end{array}$ & \multicolumn{2}{|l|}{ Thermal arrests ${ }^{*},{ }^{\circ} \mathrm{C}$} \\
\hline \multicolumn{7}{|c|}{ Heating $(\mathrm{H})$ and cooling $(\mathrm{C})-$ rate $2 \mathrm{deg} / \mathrm{min}$} \\
\hline \multicolumn{7}{|c|}{ (Fig. 1c) } \\
\hline \multirow{2}{*}{23} & \multirow{2}{*}{4.00} & \multirow{2}{*}{16.00} & \multirow{2}{*}{60.00} & \multirow{2}{*}{20.00} & $58.5 ; 168.8 ; 270.4$ & $\mathrm{H}$ \\
\hline & & & & & $57.4 ; 165.8 ; 241.7$ & $\mathrm{C}$ \\
\hline \multirow{2}{*}{25} & \multirow{2}{*}{3.00} & \multirow{2}{*}{12.00} & \multirow{2}{*}{45.00} & \multirow{2}{*}{40.00} & $58.2 ; 151.8 ; 168.2 ; 325.5$ & $\mathrm{H}$ \\
\hline & & & & & $56.1 ; 163.0 ; 353.5$ & $\mathrm{C}$ \\
\hline \multirow{2}{*}{27} & \multirow{2}{*}{2.00} & \multirow{2}{*}{8.00} & \multirow{2}{*}{30.00} & \multirow{2}{*}{60.00} & $58.3 ; 148.2 ; 167.5 ; 360.2$ & $\mathrm{H}$ \\
\hline & & & & & $56.1 ; 162.9 ; 353.8$ & \\
\hline \multicolumn{7}{|c|}{ (Fig. 1f) } \\
\hline \multirow{2}{*}{51} & \multirow{2}{*}{7.92} & \multirow{2}{*}{15.83} & \multirow{2}{*}{71.25} & \multirow{2}{*}{5.00} & $77.8 ; 162.4 ; 170.1$ & $\mathrm{H}$ \\
\hline & & & & & $76.2 ; 155.0 ; 168.1$ & $\mathrm{C}$ \\
\hline \multirow{2}{*}{53} & \multirow{2}{*}{6.67} & \multirow{2}{*}{13.33} & \multirow{2}{*}{60.00} & \multirow{2}{*}{20.00} & $77.7 ; 167.7 ; 254.5$ & $\mathrm{H}$ \\
\hline & & & & & $163.1 ; 247.9$ & $\mathrm{C}$ \\
\hline \multirow{2}{*}{57} & \multirow{2}{*}{3.33} & \multirow{2}{*}{6.67} & \multirow{2}{*}{30.00} & \multirow{2}{*}{60.00} & $78.9 ; 167.7 ; 362.9$ & $\mathrm{H}$ \\
\hline & & & & & $157.9 ; 355.5$ & $\mathrm{C}$ \\
\hline
\end{tabular}

\begin{tabular}{|c|c|c|c|c|c|c|}
\hline \multicolumn{7}{|c|}{ (Fig. 1i) } \\
\hline 87 & 4.29 & 5,71 & 30.00 & 60.00 & $77.9 ; 166.4 ; 364.3$ & $\mathrm{H}$ \\
\cline { 5 - 6 } & & & & $160.2 ; 358.8$ & $\mathrm{C}$ \\
\hline 89 & 2.14 & 2.86 & 15.00 & 80.00 & $78.4 ; 166.5 ; 368.7 ; 384.1$ & $\mathrm{H}$ \\
\cline { 5 - 6 } & & & & $161.7 ; 377.4$ & $\mathrm{C}$ \\
\hline
\end{tabular}

"mean of two cycles.

TABLE $2 b$

The results of DTA experiments for quaternary Bi-In-Sn-Zn alloys (samples 37, 38 and 68) acquired

by DTA/DSC Pegasus 404 F1 (Netzsch, Germany)

\begin{tabular}{|c|c|c|c|c|c|c|}
\hline $\begin{array}{c}\text { Sample } \\
\text { no. }\end{array}$ & $\begin{array}{c}\text { Bi } \\
\text { at. \% }\end{array}$ & $\begin{array}{c}\text { In } \\
\text { at. \% }\end{array}$ & $\begin{array}{c}\text { Sn } \\
\text { at. \% }\end{array}$ & $\begin{array}{c}\text { Zn } \\
\text { at. \% }\end{array}$ & \multicolumn{2}{|l|}{ Thermal arrests*, ${ }^{\circ} \mathbf{C}$} \\
\hline \multicolumn{7}{|c|}{ (in Fig. 1d) } \\
\hline \multicolumn{7}{|c|}{ Heating $(\mathrm{H})$ and cooling $(\mathrm{C})-$ rate $5 \mathrm{deg} / \mathrm{min}$} \\
\hline \multirow{2}{*}{37} & \multirow{2}{*}{10.00} & \multirow{2}{*}{20.00} & \multirow{2}{*}{10.00} & \multirow{2}{*}{60.00} & $\begin{array}{c}60.5 ; 63.1 ; 68.6 ; 76 \\
385.1 ; 420.0\end{array}$ & $\mathrm{H}$ \\
\hline & & & & & $\begin{array}{c}60.5 ; 64.2 ; 80.1 ; 385 ; \\
419.6\end{array}$ & $\mathrm{C}$ \\
\hline \multirow[t]{2}{*}{38} & \multirow[t]{2}{*}{7.50} & \multirow[t]{2}{*}{15.00} & \multirow[t]{2}{*}{7.50} & \multirow[t]{2}{*}{70.00} & $\begin{array}{c}60.7 ; 70.8 ; 76.7 ; 384.3 ; \\
429.5\end{array}$ & $\mathrm{H}$ \\
\hline & & & & & $64.6 ; 77.7 ; 384.4 ; 438.1$ & $\mathrm{C}$ \\
\hline \multicolumn{7}{|c|}{ Heating $(\mathrm{H})$ and cooling $(\mathrm{C})-$ rate $2 \mathrm{deg} / \mathrm{min}$} \\
\hline \multirow[t]{2}{*}{37} & \multirow[t]{2}{*}{10.00} & \multirow[t]{2}{*}{20.00} & \multirow[t]{2}{*}{10.00} & \multirow[t]{2}{*}{60.00} & $\begin{array}{c}58.8 ; 61.8 ; 67.0 ; 70.4 ; \\
80.8 ; 380 ; 385.1 ; 391.7 \\
431.2\end{array}$ & $\mathrm{H}$ \\
\hline & & & & & $\begin{array}{c}54.8,57.2 ; 59.6 ; 77.4 ; \\
384.1 ; 436.1\end{array}$ & $\mathrm{C}$ \\
\hline \multirow[t]{2}{*}{38} & \multirow[t]{2}{*}{7.50} & \multirow[t]{2}{*}{15.00} & \multirow[t]{2}{*}{7.50} & \multirow[t]{2}{*}{70.00} & $\begin{array}{c}\text { 58.7; 60.9; } 67.2 ; 71.4 \\
79.5 ; 383.5 ; 385.5 \\
414.6\end{array}$ & $\mathrm{H}$ \\
\hline & & & & & $\begin{array}{c}54.7 ; 59.5 ; 78.1 ; 381.5 \\
383.2 ; 413.9 \\
\end{array}$ & $\mathrm{C}$ \\
\hline \multicolumn{7}{|c|}{ (in Fig. 1g) } \\
\hline \multicolumn{7}{|c|}{ Heating $(\mathrm{H})$ and cooling $(\mathrm{C})-$ rate $5 \mathrm{deg} / \mathrm{min}$} \\
\hline \multirow{2}{*}{68} & \multirow{2}{*}{9.64} & \multirow{2}{*}{12.86} & \multirow{2}{*}{7.50} & \multirow{2}{*}{70.00} & $\begin{array}{c}63.3 ; 69.6 ; 79.9 ; 87.4 \\
386.9 ; 454.5 \\
\end{array}$ & $\mathrm{H}$ \\
\hline & & & & & $\begin{array}{c}60.9 ; 63.2 ; 66.7 ; 77.8 ; \\
389.7 ; 454.8 \\
\end{array}$ & $\mathrm{C}$ \\
\hline \multicolumn{7}{|c|}{ Heating $(\mathrm{H})$ and cooling $(\mathrm{C})-$ rate $2 \mathrm{deg} / \mathrm{min}$} \\
\hline \multirow[t]{2}{*}{68} & \multirow[t]{2}{*}{9.64} & \multirow[t]{2}{*}{12.86} & \multirow[t]{2}{*}{7.50} & 70.00 & $\begin{array}{c}59.0 ; 62.3 ; 72.4(\mathrm{~b}) \\
77.2 ; 81.9 ; 382.6 ; 389.8 \\
452.7 \\
\end{array}$ & $\mathrm{H}$ \\
\hline & & & & & $\begin{array}{c}55.0 ; 59.2 ; 65.2 ; 75.0 \\
385.6 ; 389.0 ; 453.5\end{array}$ & $\mathrm{C}$ \\
\hline
\end{tabular}

${ }^{*}$ mean of two cycles, (b) - beginning of signal change.

\section{Phase equilibria calculations}

\subsection{Thermodynamic modelling}

The phases of the terminal solutions: ((Bi), (In), (Sn), (Zn)), $\alpha_{1}, \gamma$-InSn and Liquid (L) (denoted according to Table 3) are modelled with the use of a random substitutional solution. The Gibbs energy of these phases in the quaternary Bi-In-Sn-Zn system can be described in the following form:

$$
\begin{gathered}
G^{\varphi}={ }^{\varphi} G^{r e f}+{ }^{\varphi} G^{i d}+{ }^{\varphi} G_{b i n}^{e x}+{ }^{\varphi} G_{\text {ter }}^{e x} \\
\left(\varphi=(\mathrm{Bi}),(\mathrm{In}),(\mathrm{Sn}),(\mathrm{Zn}), \alpha_{1}, \gamma-\mathrm{InSn} \text { and } \mathrm{L}\right)
\end{gathered}
$$


where: ${ }^{\varphi} G^{r e f}+{ }^{\varphi} G^{i d}$ is the sum of the mechanical mixture and the ideal mixing Gibbs energy terms, ${ }^{\varphi} G_{b i n}^{e x}$ is the excess Gibbs free energy of the binary alloys approximated from the Gibbs energies of the subsystems with the use of the Muggianu extrapolation formula [11] and ${ }^{\varphi} G_{t e r}^{e x}$ is the correction function of the ternary interactions in the alloys. The excess terms represent the composition dependence of the Gibbs energy of the phases $(\varphi)$.

TABLE 3

Detailed information about the phases in the Bi-In-Sn-Zn system

\begin{tabular}{|c|c|c|}
\hline $\begin{array}{c}\text { Name, (symbol in phase diagram } \\
\text { and in TDB database) }\end{array}$ & $\begin{array}{c}\text { Pearson's } \\
\text { symbol }\end{array}$ & Constitution \\
\hline Liquid, $\mathrm{L}$ & & $(\mathrm{Bi}, \mathrm{In}, \mathrm{Sn}, \mathrm{Zn})$ \\
\hline Rhombohedral-A7, $(\mathrm{Bi})$ & $\mathrm{hR} 2$ & $(\mathrm{Bi}, \mathrm{In}, \mathrm{Sn}, \mathrm{Zn})$ \\
\hline Tetragonal-A6, $(\mathrm{In})$ & $\mathrm{tI} 2$ & $(\mathrm{Bi}, \mathrm{In}, \mathrm{Sn}, \mathrm{Zn})$ \\
\hline $\mathrm{Bct}-\mathrm{A} 5,(\mathrm{Sn})$ & $\mathrm{tI} 4$ & $(\mathrm{Bi}, \mathrm{In}, \mathrm{Sn}, \mathrm{Zn})$ \\
\hline $\mathrm{Hcp}-\mathrm{Zn}(\mathrm{Zn})$ & $\mathrm{hP} 2$ & $(\mathrm{Bi}, \mathrm{In}, \mathrm{Sn}, \mathrm{Zn})$ \\
\hline $\mathrm{BiIn}$ & $\mathrm{tP} 4$ & $(\mathrm{Bi})_{1 / 2}(\mathrm{In})_{1 / 2}$ \\
\hline $\mathrm{Bi}_{3} \mathrm{In}_{5}$ & $\mathrm{tI} 32$ & $(\mathrm{Bi})_{3 / 8}(\mathrm{In})_{5 / 8}$ \\
\hline $\mathrm{BiIn}_{2}$ & $\mathrm{hP} 6$ & $(\mathrm{Bi})_{1 / 3}(\mathrm{In})_{2 / 3}$ \\
\hline Tetragonal-A6, $\left(\alpha_{1}\right)$ & $\mathrm{t} 2$ & $(\mathrm{Bi}, \mathrm{In}, \mathrm{Sn})$ \\
\hline$\gamma$-InSn, $(\gamma)$ & $\mathrm{hP} 5$ & $(\mathrm{In}, \mathrm{Sn})$ \\
\hline & &
\end{tabular}

The temperature dependence of the molar Gibbs energy of the pure elements, referred to the standard state, is given by the following expression, according to the Scientific Group Thermodata Europe (SGTE) [12].

The calculations were performed with the use of the following relations describing the excess Gibbs free energy of the quaternary alloys:

$$
{ }^{\varphi} G_{b i n}^{e x}=\sum_{i<j} \sum_{i} x_{j}{ }^{\varphi} L_{i j}
$$

representing Redlich-Kister sum of binaries [13], where:

$$
{ }^{\varphi} L_{i j}=\sum_{k=0}^{m_{i j}} \varphi L_{i j}^{(k)}\left(x_{i}-x_{j}\right)^{k}
$$

and $x_{i,(j, k, l)}$ are the mole fractions of components $i, j, k, l$ and $L_{i j}$ are the interaction parameters of the binary alloys calculated in the course of optimization of the thermodynamic properties of the binary alloys. $T$ is the temperature at the absolute scale. The coefficients ${ }^{\varphi} L_{i j}^{(k)}$ of the Redlich-Kister equation [12] can also be a function of temperature, according to Eq. 4, and they were assessed on the basis of the available equilibrium experimental data.

$$
{ }^{\varphi} L_{i j}^{(k)}={ }^{\varphi} A_{i j}^{(k)}+{ }^{\varphi} B_{i j}^{(k)} T
$$

In the case of the ternary alloys, the thermodynamic model was completed by the ternary interaction term:

$$
{ }^{\varphi} G_{t e r}^{e x}=\sum \sum_{i<j<k} \sum_{i} x_{j} x_{k}{ }^{\varphi} L_{i j k}
$$

The composition dependence of the ternary interaction parameter ${ }^{\varphi} L_{i j k}$ is given by the following assessed parameters ${ }^{\varphi} L_{i,(j, k)}$ :

$$
{ }^{\varphi} L_{i j k}=x_{i}{ }^{\varphi} L_{i}+x_{j}{ }^{\varphi} L_{j}+x_{k}{ }^{\varphi} L_{k}
$$

In present calculations the quaternary interaction term was not taken into account.

The stoichiometric phases of the binary $\mathrm{BiIn}, \mathrm{Bi}_{3} \mathrm{In}_{5}$ and $\mathrm{BiIn}_{2}$ were described with the use of the simple assumption of the Kopp-Neumann rule [14], i.e. by a floating reference state:

$$
\begin{aligned}
{ }^{0} G^{B i_{p} I n_{q}}= & p^{0} G_{B i}^{\text {Rhombohedral }-A 7}(T)+ \\
& +q^{0} G_{\text {In }}^{\text {Tetragonal }-A 6}(T)+A_{p q}+B_{p q} \cdot T
\end{aligned}
$$

where: $p$ and $q$ are the stoichiometric coefficients.

${ }^{0} G_{B i}^{\text {Rhombohedral }-A 7}(T)$ and ${ }^{0} G_{I n}^{\text {Tetragonal }-A 6}(T)$ are the standard SER functions for elemental $\mathrm{Bi}$ and $\mathrm{In}$, respectively. The assessed enthalpy and entropy parameters $A_{p q}$ and $B_{p q}$ of the Gibbs free energy of the formation of the $\mathrm{BiIn}, \mathrm{Bi}_{3} \mathrm{In}_{5}$ and $\mathrm{BiIn}{ }_{2}$ compounds taken from the assessment of Boa and Ansara [15] has been stored in the COST 531 ver. 3.0 database [16,17] of June 2008 version.

The thermodynamic description of quaternary Bi-In-Sn-Zn system was combined from assessments of six constituent ternary systems. It is a common practice for multicomponent systems because of lack of thermodynamic data. Detailed information on the phases in the Bi-In-Sn-Zn system is given in Table 3. The additional stable ternary and quaternary phases in the Bi-In-Sn$\mathrm{Zn}$ system were not reported. The tin diamond crystal structure, which is stable below $286 \mathrm{~K}\left(13^{\circ} \mathrm{C}\right)$, is not considered here.

Phase equilibria in the Bi-In-Sn-Zn system were determined by the Pandat software ver. 8.1 (CompuTherm LLT, USA) [18, 19]. The parameters of the Gibbs energy of metals and the interaction parameters of the liquid and solid phases were taken from the COST531 ver. 3.1 data base [7]. In this database the assessment of the Bi-Zn system was based on Malakhov's system optimization [20] with an improvement of the new data for the solubility of $\mathrm{Bi}$ in the hcp-Zn terminal phase [21]. The thermodynamic modelling of Lee et al. [22], with some amendments of the In-Zn interaction parameters of the binary solid phases, was adopted for the In-Zn system. According to the assessment of Vizdal et al. [21], the datasets for the Bi-Sn and Bi-Sn-Zn systems were included in the COST531 database [7].

The interaction parameters for the liquid Bi-In-Zn solutions were elaborated on the basis of the experimental data which have been published in the recent years and the DTA data presented by Onderka et al. [4]. In the case of the Bi-In-Sn system, the thermodynamic parameters were taken from the assessment of Yoon et al. [23], with some later modification [7].

The ternary parameters of the liquid solution in the In-Sn$\mathrm{Zn}$ system were obtained from the thermodynamic assessment of Cui et al. [24].

The parameters of Bi-In-Sn [8,9] assessment was not used in present calculations because it contains new Bi-In assessment which has not been implemented in COST 531 ver. 3.0 database $[16,17]$ up till the conclusion of present paper.

All the thermodynamic parameters which have been used in this work are listed in Table 4. Some positive binary interaction 
1950

TABLE 4

TDB Database of Bi-In-Sn-Zn system (298.15-2000 K). Model parameters from COST 531 v.3.0 database [16, 17] and from [3]. The Gibbs free energy of pure elements (also SER) in phases were not enclosed

(Sn) (Bi, In, Sn, Zn)

$$
\begin{aligned}
& { }^{0} G_{B i, I n}^{(S n)}=5000 \\
& { }^{0} G_{B i, S n}^{(S n)}=3500-1.038 \cdot T \\
& { }^{1} G_{B i, S n}^{(S n)}=-3710 \\
& { }^{0} G_{B i, Z n}^{(S n)}=50 \cdot T^{(a)} \\
& { }^{0} G_{I n, Z n}^{(S n)}=3500 \\
& { }^{0} G_{S n, Z n}^{(S n)}=6514.8+25.7096 \cdot T \\
& { }^{0} G_{B i, I n, S n}^{(S n)}=-1000 \\
& { }^{1} G_{B i, I n, S n}^{(S n)}=-1000 \\
& { }^{2} G_{B i, I n, S n}^{(S n)}=-33000
\end{aligned}
$$

$\mathbf{B i}_{3} \mathbf{I n}_{\mathbf{5}}(\mathrm{Bi})_{0.375}(\mathrm{In})_{0.625}$

$$
\begin{aligned}
{ }^{0} G_{\mathrm{Sn}, \mathrm{Zn}}^{B i_{3} n_{5}}= & -544-4.12287 \cdot \mathrm{T}+0.375 \cdot{ }^{\circ} G_{B i}^{\text {Rhombo_A7 }}+ \\
& +0.625 \cdot{ }^{\circ} G_{\text {In }}^{\text {Tetrag_A6 }}
\end{aligned}
$$

BiIn $(\mathrm{Bi})_{0.5}(\mathrm{In})_{0.5}$

$$
{ }^{0} G_{B i, I n}^{\text {Biln }}=-732.2-3.7906 \cdot \mathrm{T}+0.5 \cdot{ }^{\circ} G_{B i}^{\text {Rhombo_A7 }}+0.5 \cdot{ }^{\circ} G_{l n}^{\text {Tetra_ } A 6}
$$

$\operatorname{BiIn}_{2}(\mathrm{Bi})_{0.3333}(\mathrm{In})_{0.6667}$

$$
\begin{aligned}
{ }^{0} G_{B \mathrm{~B}, \mathrm{In}}^{\text {Biln }}= & -481.1-4.188 \cdot \mathrm{T}+0.3333 \cdot{ }^{0} \mathrm{G}_{B i}^{\text {Rhombo_A7 }}+ \\
& +0.6667 \cdot{ }^{\circ} G_{I n}^{\text {Tetrag_A6 }}
\end{aligned}
$$

(Zn) (Bi, In, Sn, Zn)

$$
\begin{aligned}
{ }^{0} G_{B i}^{(Z n)} & =9901-11.8 \cdot \mathrm{T}+{ }^{0} G_{B i}^{\text {Rhombo_A7 }} \\
{ }^{0} G_{B i, S n}^{(Z n)} & =2000 \\
{ }^{0} G_{B i, Z n}^{(Z n)} & =25000 \\
{ }^{o} G_{I n, S n}^{(Z n)} & =5000+2 \cdot T \\
{ }^{0} G_{I n, Z n}^{(Z n)} & =23114 \\
{ }^{0} G_{S n, Z n}^{(Z n)} & =33433.9-11.145 \cdot T
\end{aligned}
$$

$\gamma$-InSn (In, Sn)

$$
\begin{aligned}
& { }^{0} G_{I n}^{\gamma-I n S n}=6000-2 \cdot T+{ }^{0} G_{I n}^{\text {Tetrag_A6 }} \\
& { }^{0} G_{S n}^{\gamma-I n S n}=625.5-1.1350 \cdot \mathrm{T}+{ }^{0} G_{S n}^{B c t A 5} \\
& { }^{0} G_{I n, S n}^{\gamma-I n S n}=-4916+1.6387 \cdot \mathrm{T}
\end{aligned}
$$

LIQUID (Bi, In, Sn, Zn)

$$
\begin{aligned}
& { }^{0} G_{\text {Bi,ln }}^{\text {Liquid }}=-7165-0.3754 \cdot \mathrm{T} \\
& { }^{1} G_{\text {Bi,In }}^{\text {Liquid }}=1503.8-0.5418 \cdot \mathrm{T} \\
& { }^{2} G_{\mathrm{Bi}, \mathrm{In}}^{\text {Liquid }}=1221.2-1.6597 \cdot \mathrm{T} \\
& { }^{3} G_{\text {Bi,ln }}^{\text {Liquid }}=-1627+2.764 \cdot \mathrm{T}
\end{aligned}
$$

$$
\begin{aligned}
& { }^{0} G_{\mathrm{Bi}, \mathrm{Sn}}^{\text {Liquid }}=500+1.5 \cdot \mathrm{T} \\
& { }^{1} G_{\mathrm{Bi}, \mathrm{Sn}}^{\text {Liquid }}=-100-0.135 \cdot \mathrm{T} \\
& { }^{0} G_{\mathrm{Bi}, \mathrm{Zn}}^{\text {Liquid }}=18265.1-8.6763 \cdot \mathrm{T} \\
& { }^{1} G_{\text {Bi,Zn }}^{\text {Liquid }}=-6061.2+0.7958 \cdot \mathrm{T} \\
& { }^{2} G_{B i, Z n}^{\text {Liquid }}=-6422.6+11.7197 \cdot \mathrm{T} \\
& { }^{3} G_{\text {Bi,Zn }}^{\text {Liquid }}=7227.4-9.2905 \cdot T \\
& { }^{4} G_{\text {Bi,Zn }}^{\text {Liquid }}=21123.1-27.1471 \cdot \mathrm{T} \\
& { }^{5} G_{B i, Z n}^{\text {Liquid }}=-20747.6+22.0176 \cdot \mathrm{T} \\
& { }^{6} G_{B i, Z n}^{\text {Liquid }}=-7600.4+13.1596 \cdot \mathrm{T} \\
& { }^{0} G_{\mathrm{In}, \mathrm{Sn}}^{\text {Liquid }}=-828.5+0.7602 \cdot \mathrm{T}-0.1212 \cdot \mathrm{T} \cdot \ln (\mathrm{T}) \\
& { }^{1} G_{\mathrm{In}, \mathrm{Sn}}^{\text {Liquid }}=-115.6-1.40 \cdot \mathrm{T} \\
& { }^{0} G_{\ln , Z n}^{\text {Liquid }}=12401-4.4498 \cdot \mathrm{T} \\
& { }^{1} G_{\mathrm{In}, \mathrm{Zn}}^{\text {Liquid }}=-3186+1.756 \cdot \mathrm{T} \\
& { }^{2} G_{\operatorname{In}, Z n}^{\text {Liquid }}=679 \\
& { }^{0} G_{S n, Z n}^{\text {Liquid }}=19314.6-75.8995 \cdot \mathrm{T}+8.7514 \cdot \mathrm{T} \cdot \ln (\mathrm{T}) \\
& { }^{1} G_{\mathrm{Sn}, \mathrm{Zn}}^{\text {Liquid }}=-5696.3+4.202 \cdot \mathrm{T} \\
& { }^{2} G_{\mathrm{Sn}, \mathrm{Zn}}^{\text {Liquid }}=1037.2+0.9836 \cdot \mathrm{T} \\
& { }^{0} G_{\mathrm{Bi}, \mathrm{In}, \mathrm{Sn}}^{\text {Liquid }}=8743 \\
& { }^{1} G_{\mathrm{Bi}, \mathrm{In}, \mathrm{Sn}}^{\text {Liquid }}=8743 \\
& { }^{2} G_{B i, I n, Z n}^{\text {Liquid }}=8743 \\
& { }^{0} G_{B, I, I, Z n}^{\text {Liquid }}=-11397.1+0.7976 \cdot \mathrm{T} \\
& { }^{1} G_{\text {Bi,ln, } Z \mathrm{n}}^{\text {Liquid }}=7495.8 \\
& { }^{2} G_{B, \text { In,Zn }}^{\text {Liquid }}=-19544.9+16.22 \cdot \mathrm{T} \\
& { }^{0} G_{\mathrm{Bi}, \mathrm{Sn}, \mathrm{Zn}}^{\text {Liquid }}=-17690.6+33.0 \cdot \mathrm{T} \\
& { }^{1} G_{B i, S n, Z n}^{\text {Liquid }}=-2737.2-13 \cdot \mathrm{T} \\
& { }^{2} G_{B i, S n, Z n}^{\text {Liquid }}=-19259.1+0.5 \cdot \mathrm{T} \\
& { }^{0} G_{\mathrm{In}, \mathrm{Sn}, \mathrm{Zn}}^{\text {Liquid }}=-2001-3.61 \cdot \mathrm{T} \\
& { }^{1} G_{\mathrm{In}, \mathrm{Sn}, \mathrm{Zn}}^{\text {Liquid }}=832-4.2 \cdot \mathrm{T} \\
& { }^{2} G_{\ln , S n, Z n}^{\text {Liquid }}=-16257+21.2 \cdot \mathrm{T}
\end{aligned}
$$

(Bi) $(\mathrm{Bi}, \mathrm{In}, \mathrm{Sn}, \mathrm{Zn})$

$$
\begin{aligned}
& { }^{0} G_{B i, I n}^{(B i)}=22500 \\
& { }^{0} G_{B i, I n}^{(B i)}=19720-22.6 \cdot \mathrm{T} \\
& { }^{1} G_{B i, l n}^{(B i)}=-5760+13.834 \cdot \mathrm{T} \\
& { }^{0} G_{B i, Z n}^{(B i)}=10000 \\
& { }^{0} G_{I n, Z n}^{(B i)}=3500
\end{aligned}
$$


${ }^{0} G_{S n, Z n}^{(B i)}=33433.9-11.1447 \cdot \mathrm{T}$

${ }^{0} G_{B i, I n, Z n}^{\text {Liquid }}=387000$

$[16]$

(In) $(\mathrm{Bi}, \mathrm{In}, \mathrm{Sn}, \mathrm{Zn})$

$$
\begin{aligned}
& { }^{0} G_{B i, I n}^{(I n)}=5646.8-26.868 \cdot T \\
& { }^{0} G_{B i, S n}^{(I n)}=4000 \\
& { }^{0} G_{B i, Z n}^{(I n)}=10000 \\
& { }^{0} G_{I n, S n}^{(I n)}=2036-7.88412 \cdot T \\
& { }^{o} G_{I n, Z n}^{(I n)}=4430-4.4498 \cdot T \\
& { }^{1} G_{I n, Z n}^{(I n)}=9717 \\
& { }^{0} G_{S n, Z n}^{(n n)}=33433.9-11.1447 \cdot T \\
& { }^{o} G_{B i, I n, S n}^{(I n)}=10000
\end{aligned}
$$

$$
{ }^{1} G_{B i, I n, S n}^{(I n)}=8000
$$

$\boldsymbol{\alpha}_{1}(\mathrm{Bi}, \mathrm{In}, \mathrm{Sn})$

$$
\begin{aligned}
& { }^{0} G_{B i}^{\alpha_{1}}={ }^{0} G_{B i}^{\text {Rhombo_A7 }}+49.93 \\
& { }^{0} G_{I n}^{\alpha_{1}}=123-0.1988 \cdot \mathrm{T}+{ }^{0} G_{I n}^{\text {Tetrag_A6 }} \\
& { }^{0} G_{S n}^{\alpha_{1}}=5510-8.46 \cdot \mathrm{T}+{ }^{0} G_{S n}^{B c t A 5} \\
& { }^{0} G_{B i, I n}^{\alpha_{1}}=3308.4-27.257 \cdot \mathrm{T} \\
& { }^{1} G_{B i, n}^{\alpha_{1}}=-1661.4-1.644 \cdot \mathrm{T} \\
& { }^{0} G_{B i, S n}^{\alpha_{1}}=2000 \\
& { }^{0} G_{I n, S n}^{\alpha_{1}}=950.4-6.1461 \cdot \mathrm{T} \\
& { }^{0} G_{B i, I n, S n}^{\alpha_{1}}=13000 \\
& { }^{1} G_{B, I, n, S n}^{\alpha_{1}}=21000
\end{aligned}
$$

\begin{tabular}{|c|c|c|c|c|c|c|}
\hline \multirow[b]{2}{*}{$\begin{array}{c}\text { Reaction } \\
\text { type }\end{array}$} & \multirow[b]{2}{*}{ Reaction } & \multirow[b]{2}{*}{$\mathbf{T},{ }^{\circ} \mathbf{C}$} & \multicolumn{4}{|c|}{ Composition of liquid phase } \\
\hline & & & $\begin{array}{c}\text { at. } \% \\
\text { Bi }\end{array}$ & $\begin{array}{l}\text { at. } \% \\
\text { In }\end{array}$ & $\begin{array}{l}\text { at.\% } \\
\text { Sn }\end{array}$ & $\begin{array}{c}\text { at.\% } \\
\mathrm{Zn}\end{array}$ \\
\hline $\mathrm{U}_{1}$ & $\begin{array}{c}\mathrm{L}+(\mathrm{Bi}) \leftrightarrow(\mathrm{Sn})+ \\
(\mathrm{Zn})+\mathrm{BiIn}\end{array}$ & 79.3 & 38.4 & 39.5 & 21.17 & 0.93 \\
\hline $\mathrm{U}_{2}$ & $\begin{array}{c}\mathrm{L}+(\mathrm{Sn}) \leftrightarrow(\mathrm{Zn})+ \\
\gamma-\mathrm{InSn}+\mathrm{BiIn}\end{array}$ & 65.8 & 25.1 & 53.3 & 20.95 & 0.65 \\
\hline $\mathrm{U}_{3}$ & $\begin{array}{c}\mathrm{L}+\mathrm{BiIn} \leftrightarrow(\mathrm{Zn})^{+} \\
\gamma-\operatorname{InSn}+\mathrm{Bi}_{3} \operatorname{In}_{5}\end{array}$ & 56.4 & 21.6 & 58.4 & 19.48 & 0.52 \\
\hline $\mathrm{U}_{4}$ & $\begin{array}{c}\mathrm{L}+\mathrm{Bi}_{3} \mathrm{In}_{5} \leftrightarrow(\mathrm{Zn})+ \\
\gamma-\mathrm{InSn}+\mathrm{BiIn}_{2}\end{array}$ & 54.8 & 20.3 & 59.5 & 16.7 & 0.50 \\
\hline $\mathrm{E}$ & $\begin{array}{l}\mathrm{L} \leftrightarrow(\mathrm{Zn})+\alpha_{1}+ \\
\gamma \text {-InSn+BiIn }\end{array}$ & 54.2 & 19.5 & 60.1 & 19.9 & 0.50 \\
\hline
\end{tabular}

(a) parameters introduced to restrict the stability range of certain solid phases. All parameters not defined in model description are equal zero

parameters have been introduced to restrict the stability range of certain solid phases. Such parameters are marked (a) in Table 4.

The results of the invariant reaction calculations of the quaternary Bi-In-Sn-Zn system are presented in Table 5.

TABLE 5

The invariant reactions of the quaternary Bi-In-Sn-Zn system calculated in present work

$\left(\mathrm{U}_{\mathrm{i}}-\right.$ pseudoperitectic reaction, $\mathrm{E}$ - quaternary eutectic reaction [3]).

\section{Discussion}

The results of the comparison of the calculated isopleths with the experimental data obtained in the presented work are shown in Figs 1a-i. The calculated sections of the Bi-In-Sn-Zn system agree very well with the experimental data obtained from two different thermal analyzers. The slight differences between calculated and experimentally acquired invariant reactions $\left( \pm 7^{\circ} \mathrm{C}\right)$ were observed (Fig. 1c).

The experimental data of Sabbar et al. [25] obtained for the In-Sn-Zn system suggest solubility of $\mathrm{Zn}$ in the $\gamma$-InSn phase. Unfortunately, the amount of data is too limited to model this solubility. Additionally, to describe the $\mathrm{Zn}$ solubility in the $\gamma$-InSn phase the unknown expression for ${ }^{o} G_{\mathrm{Zn}}^{\gamma \text {-InSn }}$ should be estimated. So, such $\mathrm{Zn}$ solubility can expand stability of $\gamma$-InSn into compositions of ternary system. Also, the solubility of $\mathrm{Zn}$ in $\alpha_{1}$ was not modeled because of the unknown solubility data. The unknown expression for ${ }^{o} G_{\mathrm{Z}}^{\alpha_{1}}$ can be estimated from ${ }^{o} G_{\mathrm{Zn}}^{H c p}{ }^{A 3}$. Generally, the mutual solubility of tin and zinc is very low and cannot cause any significant changes in the invariant reactions.

Another problem is an adequate description of some other ternary systems. For example, it was not possible to model the correct temperature dependence of the mixing enthalpy of the liquid phase in the In-Sn-Zn system. In some regions of the diagram, the calculated temperature dependence is opposite to that which is experimentally observed [26]. In these regions, the experimentally determined mixing enthalpy increases with the increasing temperature, whereas the calculated mixing enthalpy decreases with the increasing temperature for all concentrations of the system. This negative temperature dependence in the calculated mixing enthalpy originates from the term $T \cdot \ln (T)$ introduced in the thermodynamic description of the $\mathrm{Sn}-\mathrm{Zn}$ system, but in the ternary system, apparently the temperature dependence shifts. To solve this problem, Moleans et al. [3] proposed to include the $T \cdot \ln T$ term in the description of the liquid ternary solution. However, the experimental data available up till now covers too narrow temperature and composition ranges, and their accuracy seems to be not sufficient, to do it.

The phase diagram of the Bi-In-Sn ternary system was re-examined in the study of Yoon et al. [23] and the calculated phase diagram has both similarities and dissimilarities to the previously determined one. While the phase-transition temperatures are generally in agreement, the new phase diagram represents a different nature of the quasi-binaries, the number and type of the invariant reactions, and the reaction paths [23]. It is found that the Sn-BiIn and Sn-BiIn 2 quasi-binary systems are not pseudobinaries, which eventually leads to a phase diagram with only 
1952

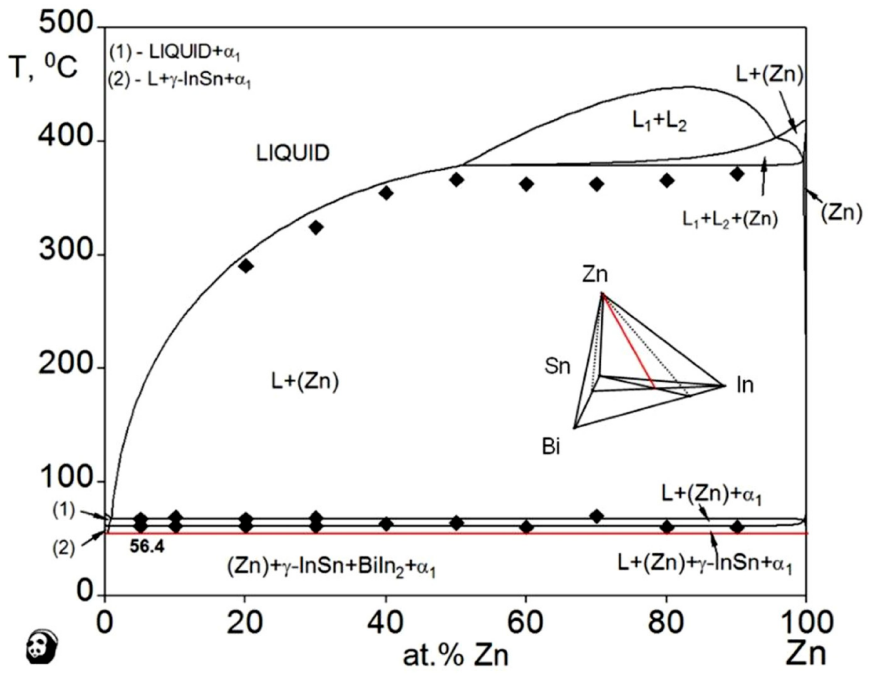

a)

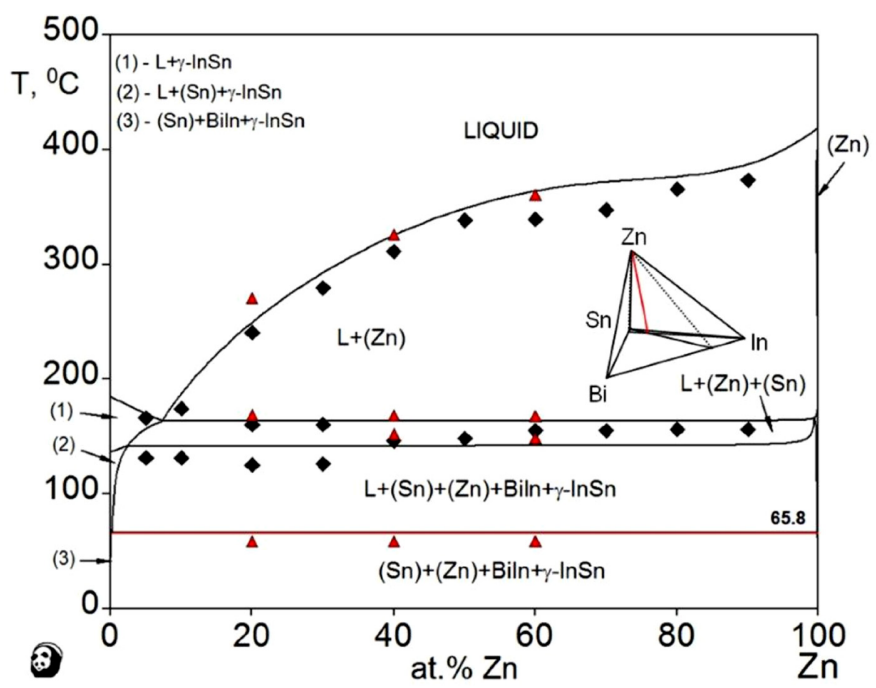

c)

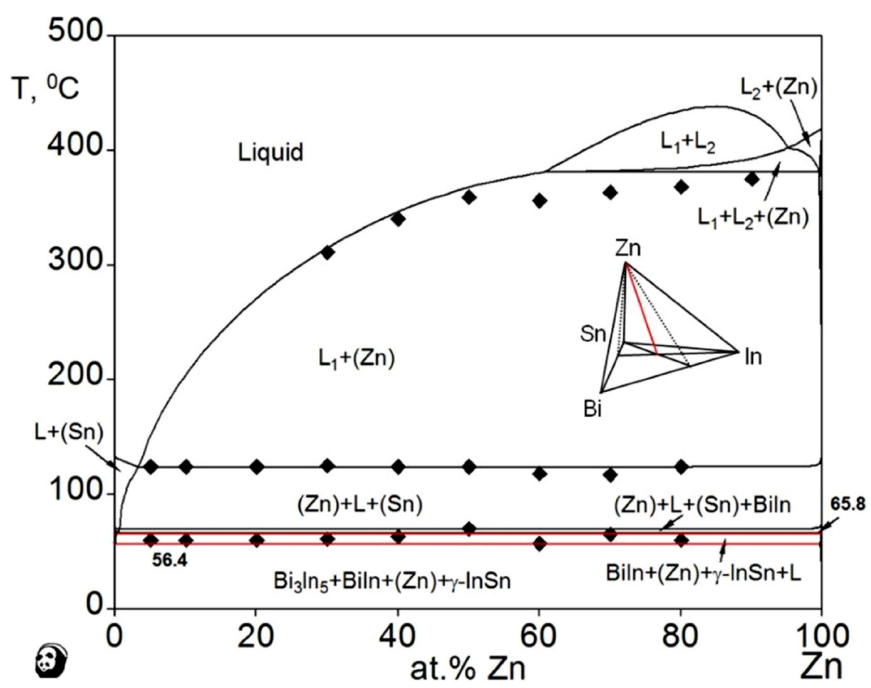

e)

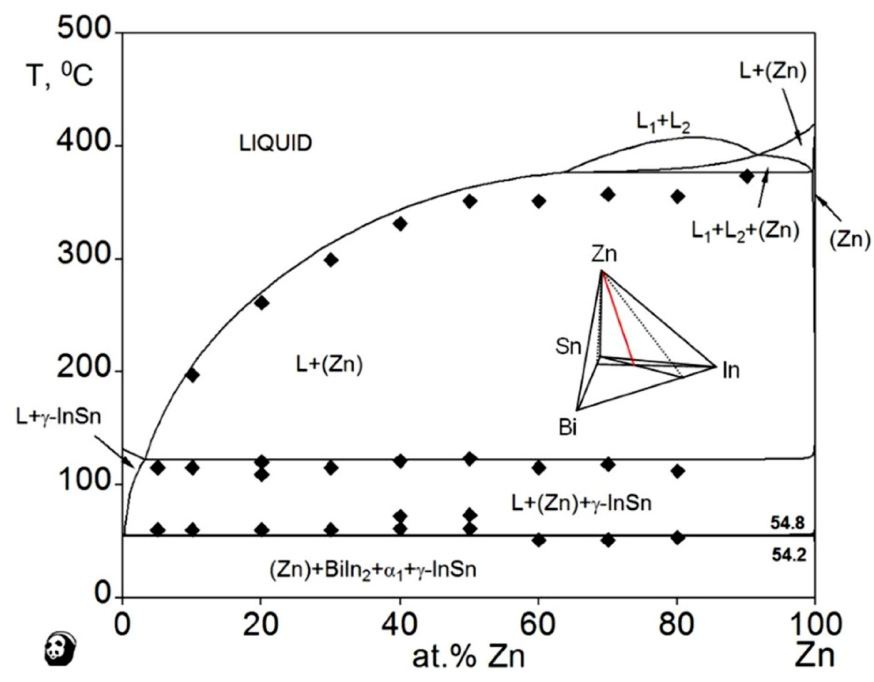

b)

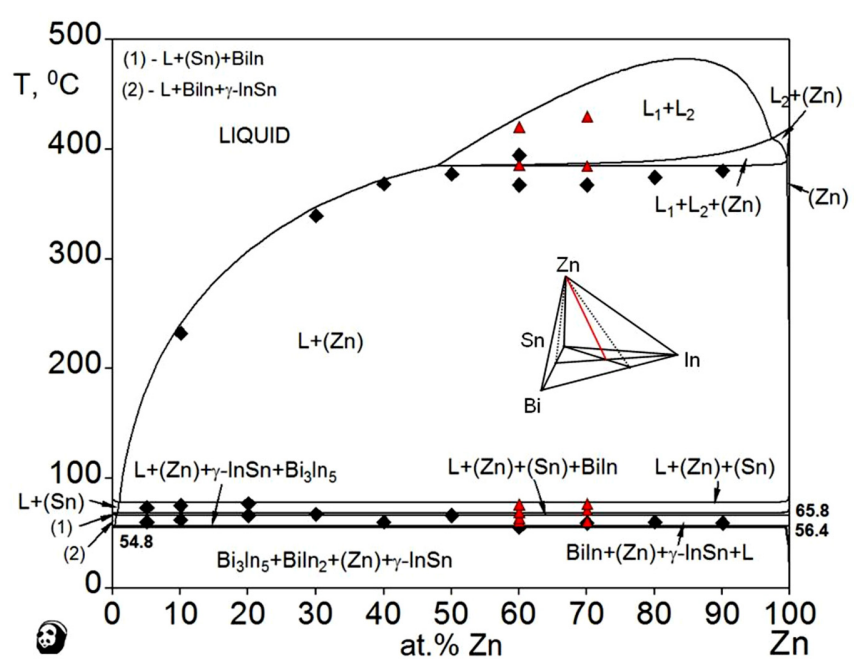

d)

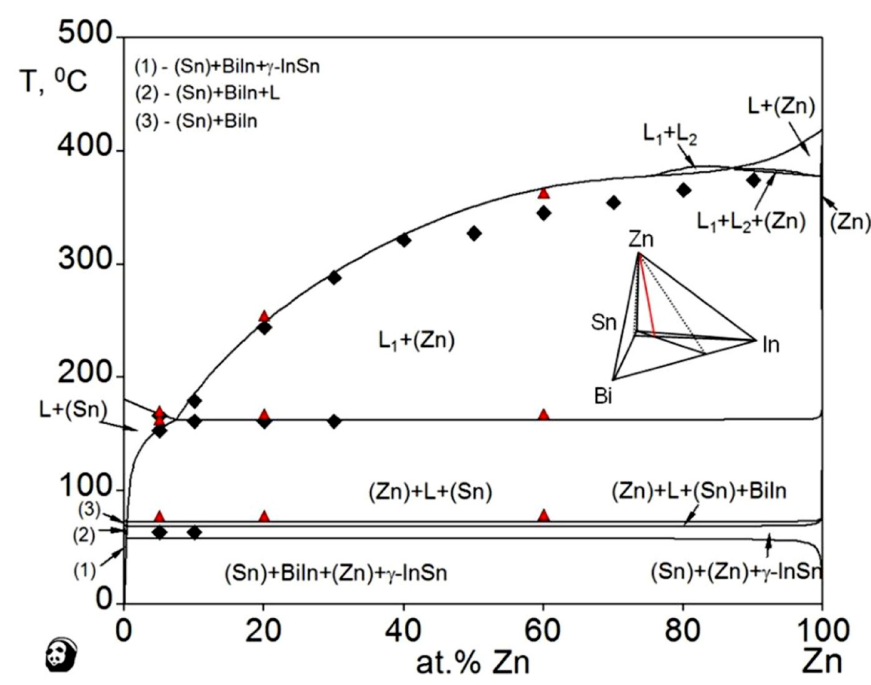

f) 


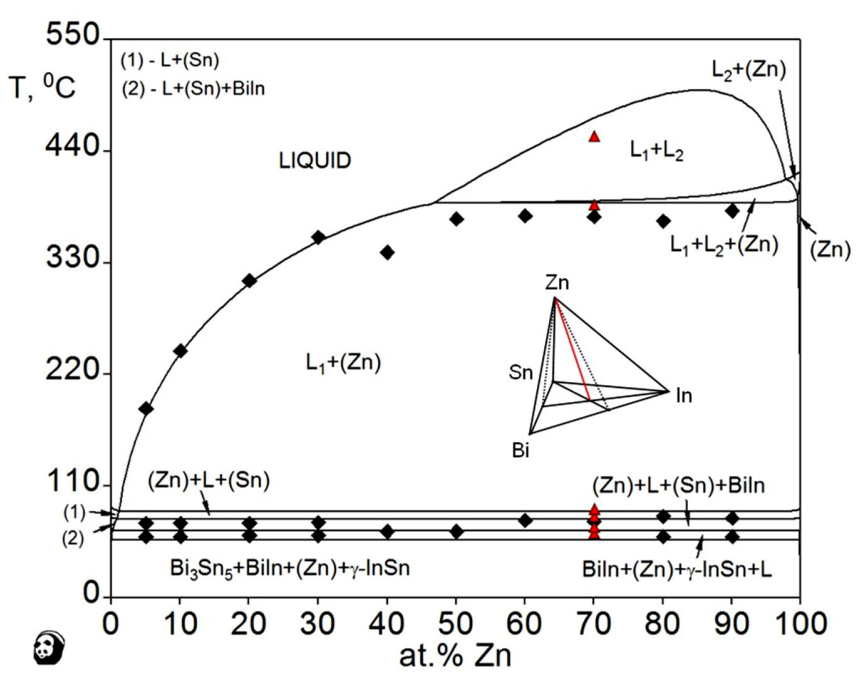

g)

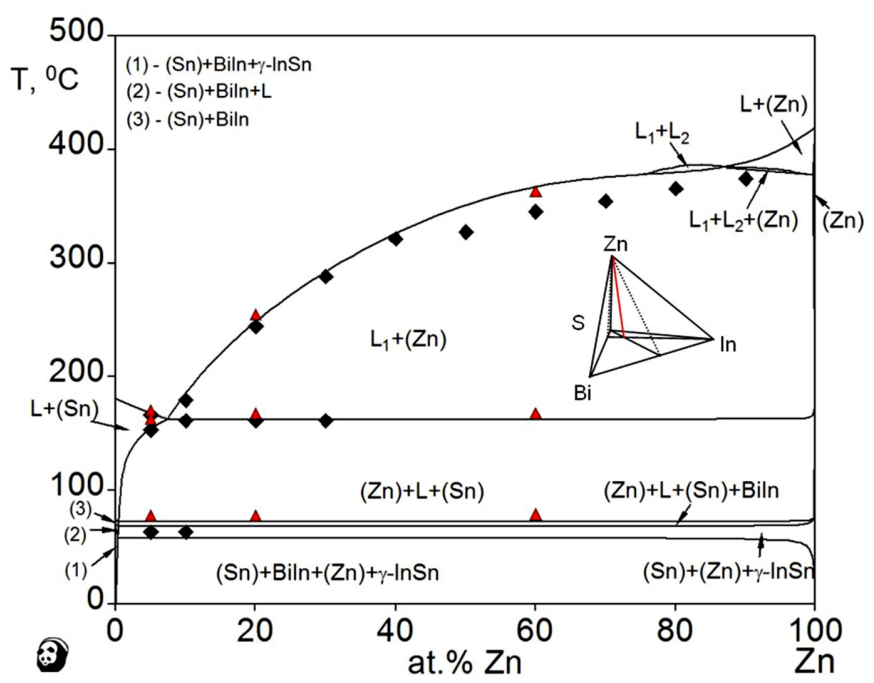

i)

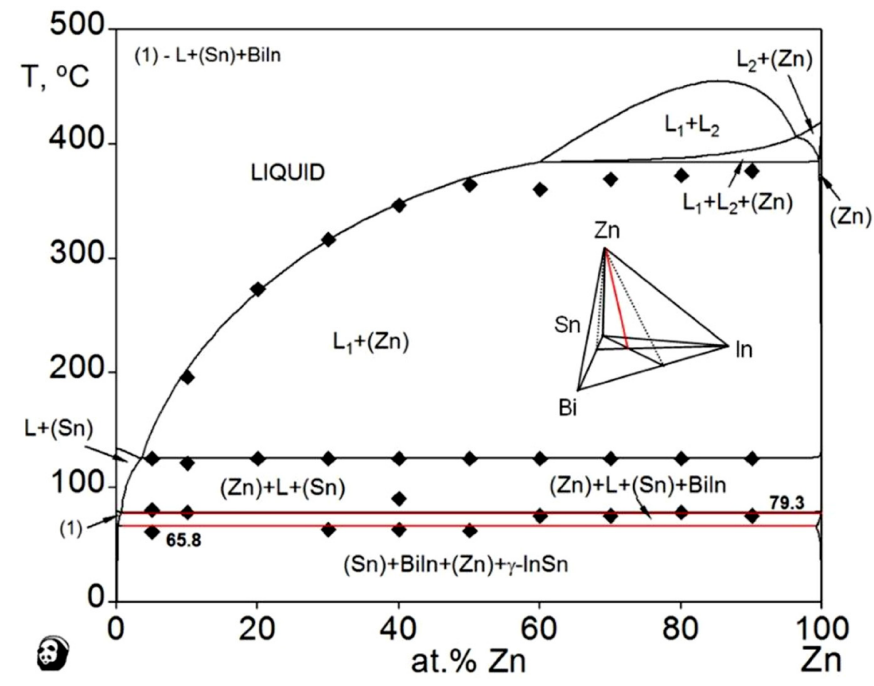

h)

a) $\mathrm{Bi}: \mathrm{In}=0.25$ and $\mathrm{Bi}: \mathrm{Sn}=0.6$

b) $\mathrm{X}_{\mathrm{Bi}}: \mathrm{X}_{\mathrm{In}}=0.25$ and $\mathrm{X}_{\mathrm{Bi}}: \mathrm{X}_{\mathrm{Sn}}=0.20$. The quaternary eutectic temperature E equals $54.2{ }^{\circ} \mathrm{C}(327.3 \mathrm{~K})$.

c) $X_{B i}: X_{I n}=0.25$ and $X_{B i}: X_{S n}=0.067$. (Additionally, Table 2a).

d) $\mathrm{X}_{\mathrm{Bi}}: \mathrm{X}_{\mathrm{In}}=0.5$ and $\mathrm{X}_{\mathrm{Bi}}: \mathrm{X}_{\mathrm{Sn}}=1$. (Additionally, Table 2b).

e) $X_{B i}: X_{I n}=0.50$ and $X_{B i}: X_{S n}=0.33$.

f) $X_{B \mathrm{~B}}: X_{I n}=0.5$ and $X_{B i}: X_{S n}=0.11$. (Additionally, Table 2a).

g) $\mathrm{X}_{\mathrm{Bi}}: \mathrm{X}_{\mathrm{In}}=0.75$ and $\mathrm{X}_{\mathrm{Bi}}: \mathrm{X}_{\mathrm{Sn}}=1.286$. (Additionally, Table 2b).

h) $\mathrm{X}_{\mathrm{Bi}}: \mathrm{X}_{\mathrm{In}}=0.75$ oraz $\mathrm{X}_{\mathrm{Bi}}: \mathrm{X}_{\mathrm{Sn}}=0.43$.

i) $X_{\mathrm{Bi}}: X_{\mathrm{In}}=0.75$ and $\mathrm{X}_{\mathrm{Bi}}: \mathrm{X}_{\mathrm{Sn}}=0.143$. (Additionally, Table 2a)

Fig. 1. Comparison of DTA data results (Tables 1a-i and Tables 2a-b) with the phase equilibria lines calculated of Bi-In-Sn-Zn system for the mole fraction ratios ( - data acquired by Q-1500 D. $\boldsymbol{\Delta}, \triangle$ - heating data acquired by Netzsch 404 DTA ( $5 \mathrm{deg} / \mathrm{min}$ and $2 \mathrm{deg} / \mathrm{min}, \mathrm{respectively}$ are not recognizable in the diagram scale)

one eutectic reaction. Other invariant reactions (eight in total) are determined to be peritectic and peritectoid [23].

In Figs 2a-b, the sequences of five thermal arrests obtained from the $2 \mathrm{deg} / \mathrm{min}$ DTA measurements of samples no. 37 and 38 are shown. Such the sequence is consistent with the calculated invariant and univariant lines of diagram in Fig. 1d, within the range of $\pm 3^{\circ} \mathrm{C}$. It should be noted that difference between calculated two pairs of invariant and univariant lines is less than $3^{\circ} \mathrm{C}$. So the match is very good. The resolution of Q-1500 D experimental data DTA data was enough (5 deg/min) to determine only one or two (5-20 at.\% Zn) thermal arrests in this temperature range.

A similar low temperature sequence of four thermal arrests was observed on the DTA curve (Fig. 3) obtained for sample no. 68. Again, this sequence is well-matched with the calculated results of four univariant lines in temperature range $\sim 55-87^{\circ} \mathrm{C}$ (328-360 K) shown in Fig. 1g.
The high temperature thermal arrests observed for samples 37 and 38 in both the heating and the cooling cycles (Fig. 1d) can be connected with the boundary of miscibility gap. It should be noted that taking into account thermodynamic description of quaternary alloys combined from assessments of constituent ternaries the consistence of calculated and experimental data are very good.

In all above described samples the difference between the calculated and experimental data of liquidus and the end of $(\mathrm{Zn})$ melting acquired by Q-1500 D can be observed in the part of higher $\mathrm{Zn}$ contents. Also the calculated miscibility gap boundaries are higher $\left(\max .25^{\circ} \mathrm{C}\right)$ then DTA results (Netzsch 404 DTA - Fig. 1d). The experimental error in this part of diagram can be connected with relatively high $\mathrm{Zn}$ partial pressure. It should be also noted that in present work it was possible to recognize in heating and cooling cycles the boundary of miscibility gap (Fig. 1d and 1g) which is known to be relatively difficult to detect. 


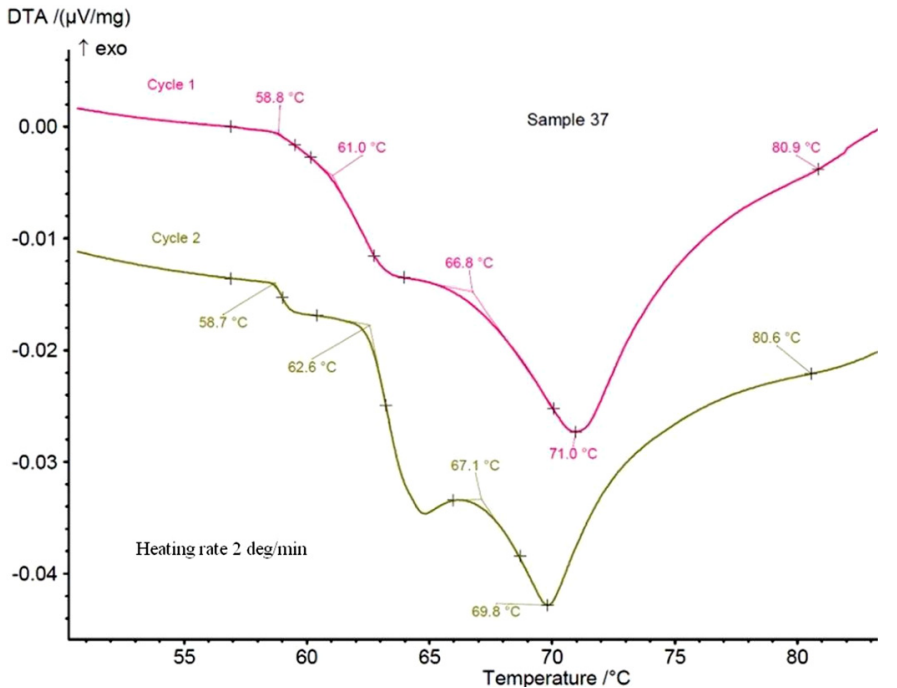

Fig. 2a. Low temperature part of DTA chart for two heating cycles of sample $37\left(\mathrm{X}_{\mathrm{Bi}}: \mathrm{X}_{\mathrm{In}}=0.50, \mathrm{X}_{\mathrm{Bi}}: \mathrm{X}_{\mathrm{Sn}}=1\right.$ and $\left.\mathrm{X}_{\mathrm{Zn}}=0.60\right)$

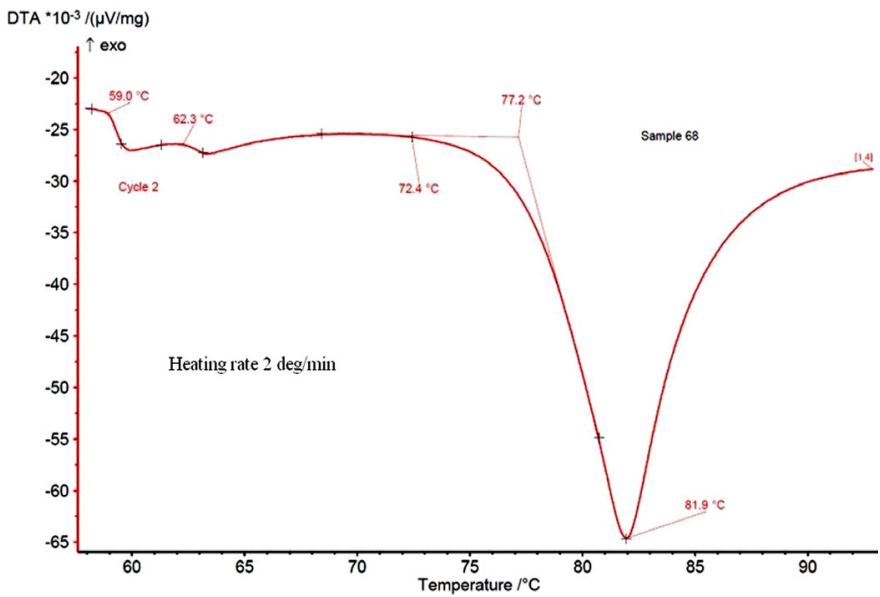

Fig. 3. Low temperature part of DTA chart for two heating cycles of sample $68\left(\mathrm{X}_{\mathrm{Bi}}: \mathrm{X}_{\mathrm{In}}=0.75, \mathrm{X}_{\mathrm{Bi}}: \mathrm{X}_{\mathrm{Sn}}=1.286\right.$ and $\left.\mathrm{X}_{\mathrm{Zn}}=0.7\right)-($ Table $2 \mathrm{~b})$

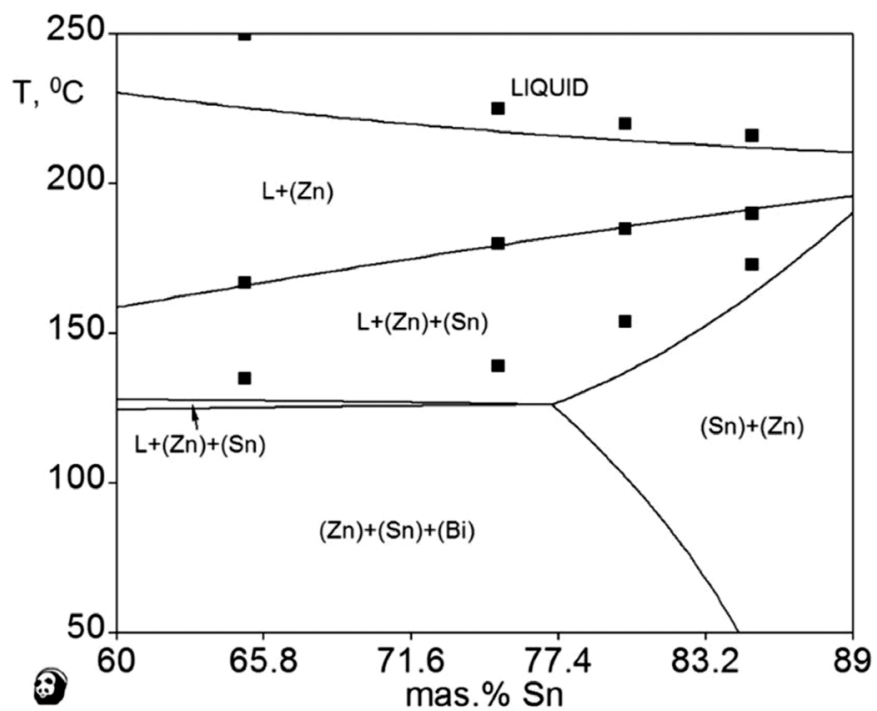

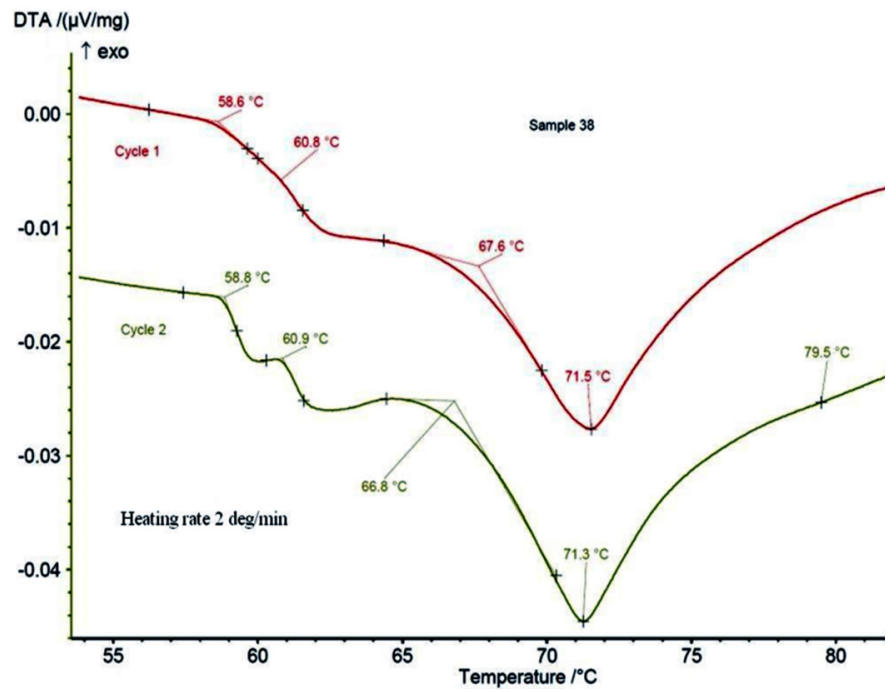

Fig. 2b. Low temperature part of DTA chart for two heating cycles of sample $38\left(\mathrm{X}_{\mathrm{Bi}}: \mathrm{X}_{\mathrm{In}}=0.50, \mathrm{X}_{\mathrm{Bi}}: \mathrm{X}_{\mathrm{Sn}}=1\right.$ and $\left.\mathrm{X}_{\mathrm{Zn}}=0.70\right)$

The comparison between the experimental data of Yoon et al. [2] and the calculated isopleths of Sn-Bi-2In-9Zn and SnBi-5In-6Zn (in mas. \%) is presented in Figs 5a-b, respectively. The composition dependence of the ( $\mathrm{Sn}$ ) dissolution limit is in very good agreement with the calculated results. Moreover, the difference in the experimental and the calculated temperatures of solidus and liquidus observed in Figs 4a-b can be connected with the unusual method of analysis of the thermal arrests found on the DSC curves performed by Yoon et al. [2].

Two years later Yoon et al. [23] reported the thermodynamic calculation of the Bi-In-Sn ternary system by the CALPHAD method despite the absence of experimental thermodynamic data available for the system. The only experimental data on this system were published by Witusiewicz et al. [8] and Rex et al. [9]. Their work gives a new data set for the ternary system

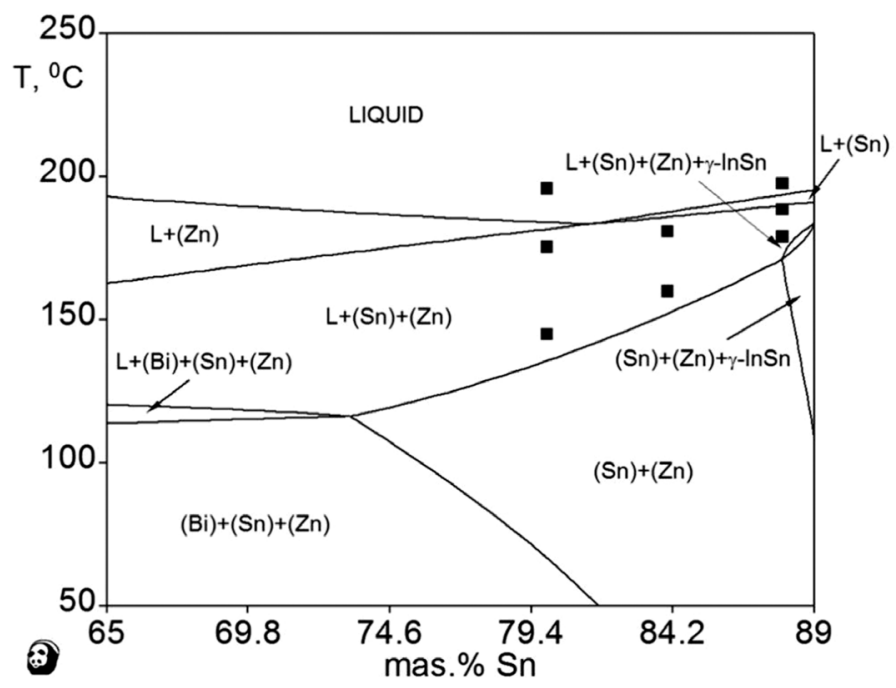

Fig. 4. Calculated isopleths of Bi-In-Sn-Zn system: (a) Sn-Bi-2In-9Zn and (b) Sn-Bi-5Sn-6Zn alloys compared with the temperature arrests measured by DSC method [2] 
considering the $\beta$ phase $\left(\mathrm{BiIn}_{9}\right)$, which is in better agreement with the experimental data than the earlier calculation. They also accepted the limiting solubility of $\mathrm{Sn}$ in the binary $\mathrm{BiIn}, \mathrm{Bi}_{3} \mathrm{In}_{5}$ and $\mathrm{BiIn}_{2}$ intermetallic phases. The solubility studies of $\mathrm{Zn}$ in the $\gamma$-InSn and $\alpha_{1}$ phase together with the critical elaboration by Witusiewicz et al. [27] which allow, in the future, to update the description of the Bi-In-Sn-Zn system.

\section{Conclusions}

With the application of the thermal differential analysis (DTA), studies of the phase transition temperatures were performed for 90 of $\mathrm{Bi}-\mathrm{In}-\mathrm{Sn}-\mathrm{Zn}$ alloys, for the mole fraction ratio of $\mathrm{Bi}$ :In equaling $0.25,0.5$ and 0.75 and for the ratio $\mathrm{Bi}: \mathrm{Sn}$ equaling $0.067,0.111,0.143,0.2,0.333,0.428,0.5,0.6,1.286$. The reliability of DTA data was tested by two types of thermal devices: Q-1500 D (Paulik-Paulik-Erdey) (MOM, Hungary) and DSC/DTA Pegasus 404 F1 (Netzsch, Germany).

Based on the critical thermodynamic evaluations (assessments) of the binary and ternary subsystems available in the literature, the calculations of the equilibrium lines of the phase transition were conducted in the quaternary Bi-In-Sn-Zn system, and compared with those measured in these studies. This is the standard practice to assess the multicomponent system from assessments of constituent ternary systems and to make some control experiments (also DTA) to check the accuracy of such description. The present work can be treated as such check of coherency of optimized ternary parameters in quaternary system database. And it seems that this check is positive because the comparative analysis of the experimental and the calculated data of the transition temperatures showed a good agreement of both sets of data.

The Bi-In-Sn-Zn alloys are important for lead-free soldering, and so the future studies should concentrate on the thermodynamic investigations of solid alloys, as their experimental data are very poor. Also, the determination of the regions of the phases' coexistence for the new elaboration of the Bi-In-Sn-Zn system is required.

\section{Acknowledgement}

This research has been supported by grant N N507 457237 from the Polish Ministry of Science and Higher Education.

\section{REFERENCES}

[1] M.E. Loomans, S. Vaynman, G. Ghosh, M.E. Fine, J. Electr. Mater 23, 741 (1994).

[2] W.Y. Yoon, J.R. Soh, H.M. Le e, B.-J. Lee, Acta Mater. 45, 951 (1997).
[3] N. Moelans, K.C.H. Kumar, P. Wollants, J. Alloys Comp. 360, 98 (2003).

[4] B. Onderka, A. Dębski, W. Gąsior, Arch. Metal. Mater. 60, 567 (2015).

[5] Z. Li, S. Knott, A. Mikula, Acta Mater. 55, 2417 (2007).

[6] S. Knott, Z. Li, C.-H. Wang, A. Mikula, Met. Mater. Trans. A 41A, 3130 (2010).

[7] A. Kroupa, A.T. Dinsdale, A. Watson, J. Vrestal, J. Vízdal, A. Zemanova, JOM 59, 20 (2007).

[8] V.T. Witusiewicz, U. Hecht, S. Rex, M. Apel, Acta Mater. 53, 3663 (2005).

[9] S. Rex, B. Böttger, V.T. Witusiewicz, U. Hecht, Mater. Sci. Engin. A413-414, 249 (2005).

[10] J. Boettinger, U.R. Kattner, K.W. Moon, J.H. Perepezko, Recommended Practice Guide: DTA \& Heat-Flux DSC Measurement of Alloy Melting and Freezing, NIST Special Publication 960-15. November 2006", [http://www.metallurgy.nist.gov/ reports/recom-mendedpractice/SP960_15.pdf book].

[11] Y.-M. Muggianu, M. Gambino, J.-P. Bros, J. Chim. Phys. 72, 83 (1975).

[12] A.T. Dinsdale, Calphad 15, 317 (1991).

[13] O. Redlich, A.T. Kister, Ind. Eng. Chem. Res. 40, 345 (1948).

[14] H.-L. Chen, E. Doernberg, P. Svoboda, R. Schmid-Fetzer, Thermochim. Acta 512, 189 (2011).

[15] D. Boa, I. Ansara, Thermochim. Acta 314, 79 (1998).

[16] A.T. Dinsdale, A. Watson, A. Kroupa, J. Vrestal, A. Zemanova, J. Vizdal, Version 2.0 of the "COST531" Database for the lead-free solders, 2006.

[17] A. Dinsdale, A. Watson, A. Kroupa, J. Vrestal, A. Zemanova, J. Vizdal, COST 531 - Lead Free Solders. Vol. 1, Atlas of Phase Diagrams for Lead-Free Soldering, European Report COST531, Brno 2008 (ISBN 978-80-86292-28-1).

[18] S.-L. Chen, F. Zhang, S. Daniel, F.-Y. Xie, X.-Y. Yan, Y.A. Chang, R. Schmid-Fetzer, W.A. Oates, JOM 55, 48 (2003).

[19] W. Cao, S.-L. Chen, F. Zhang, K. Wu, Y. Yang, Y.A. Chang, R. Schmid-Fetzer, W.A. Oates, Calphad 33, 328 (2009).

[20] D.V. Malakhov, Calphad 24, 1 (2000).

[21] J. Vizdal, M.H. Braga, A. Kroupa, K.W. Richter, D. Soares, L.F. Malheiros, J. Ferreira, Calphad 31, 438 (2007).

[22] B.-J. Lee, Calphad 20, 471 (1996).

[23] S.W. Yoon, B.-S. Rho, F.M.Lee, B.-J.Lee, Met. Mater. Trans. 30A, 1503 (1999).

[24] Y. Cui, X.J. Liu, I. Ohnuma, R. Kainuma, H. Ohtani, K. Ishida, J.Alloys Comp. 320, 234 (2001).

[25] A. Sabbar, A. Zrineh, M. Gambino, J.P. Bros, Thermochim. Acta 369 (1-2), 125 (2001).

[26] P. Anre's, M. Alaoui-Elbelghiti, M. Gambino, J.P. Bros, Thermochim. Acta 346, 49 (2000).

[27] V.T. Witusiewicz, U. Hecht, B. Böttger, S. Rex, J. Alloys Comp. 428 (1-2), 115 (2007).

[28] I. Ansara, A.T. Dinsdale, M.H. Rand, Thermochemical database for light metal alloys, EUR18499, July 1998, 288-289. 